\title{
Long-term care insurance financing using home equity release: Evidence from an online experimental survey
}

\author{
- Online Appendix - \\ Katja Hanewald ${ }^{a}$, Hazel Bateman ${ }^{a}$, Hanming Fang ${ }^{b}$ and Tin Long Ho ${ }^{a}$ \\ ${ }^{a}$ School of Risk \&Actuarial Studies, UNSW Sydney, and ARC Centre of Excellence in \\ Population Ageing Research (CEPAR) \\ ${ }^{b}$ University of Pennsylvania, ShanghaiTech University and CEPAR
}

14 January 2022

\section{Contents}

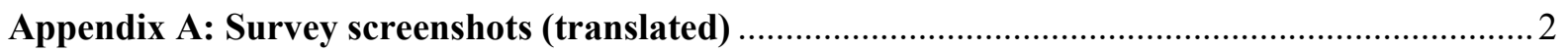

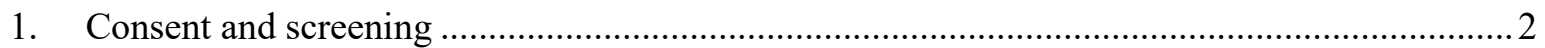

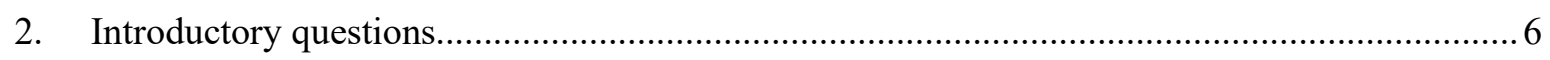

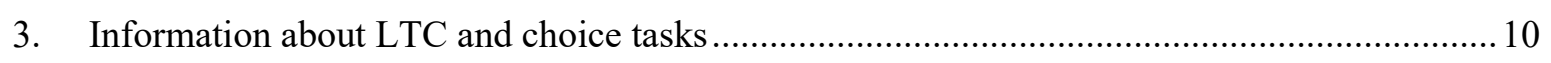

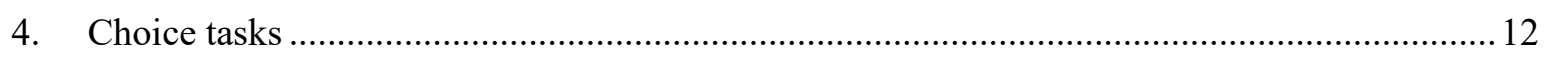

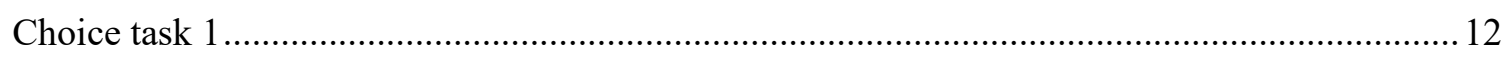

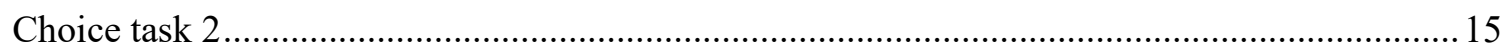

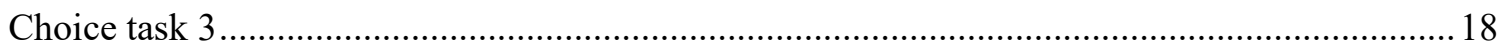

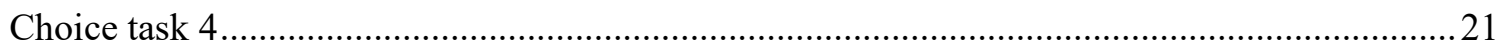

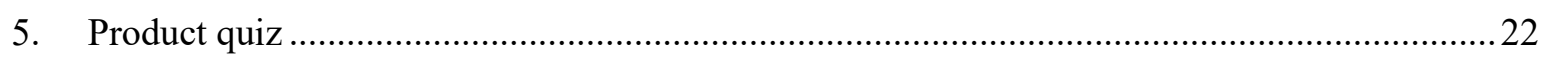

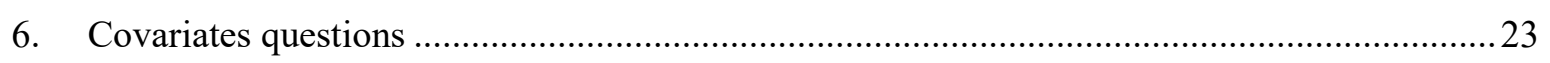

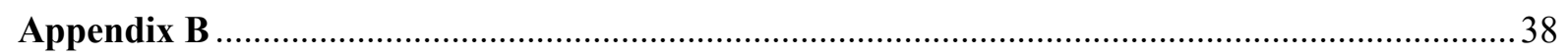

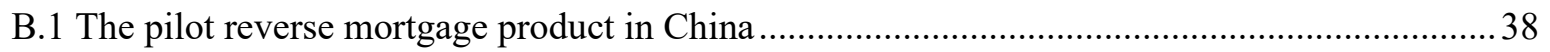

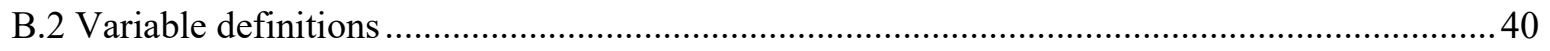

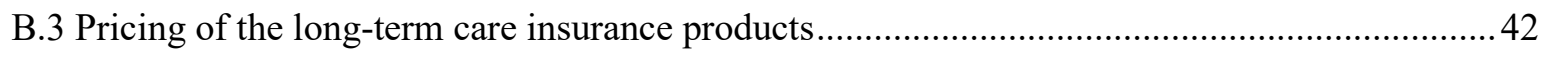

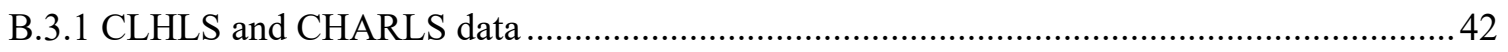

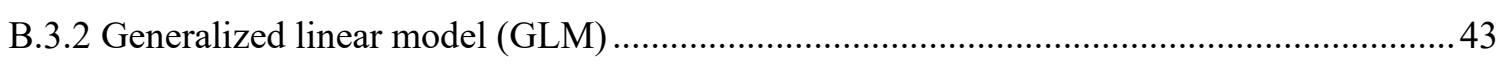

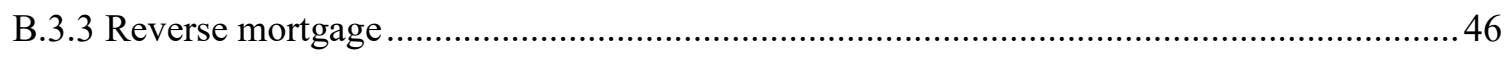

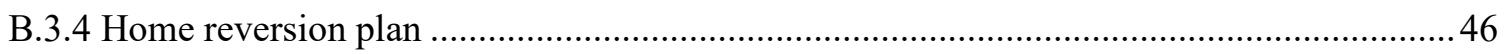

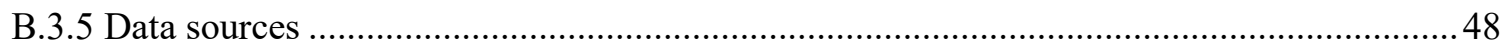

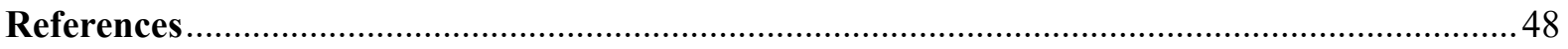




\section{Appendix A: Survey screenshots (translated)}

\section{Consent and screening}

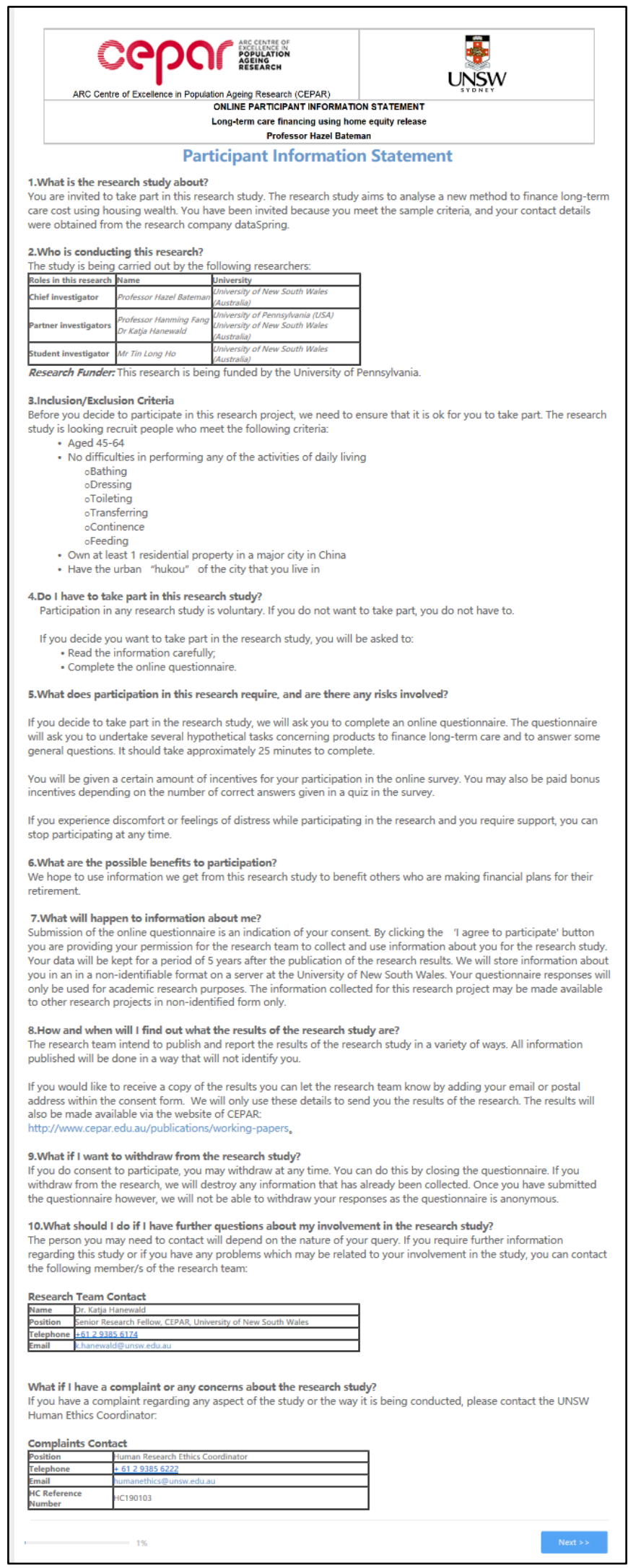




\section{Consent Form - Participant providing own consent}

You are invited to take part in this research study. The research study aims to analyse a new method to finance long-term care cost using housing wealth.

To participate in the survey, you MUST answer these questions as we need your answers to be able to ask you only relevant questions. Your answers to these questions are confidential, and cannot be used to identify you personally.

\section{Declaration by the participant}

$\square \mathrm{I}$ understand I am being asked to provide consent to participate in this research study:

$\square \mathrm{I}$ have read the Participant Information Sheet or it has been provided to me in a language that I understand;

$\square$ I provide my consent for the information collected about me to be used for the purpose of this research study only;

$\square \mathrm{I}$ understand that if necessary I can ask questions and the research team will respond to my questions;

$\square \mathrm{I}$ freely agree to participate in this research study as described and understand t hat I am free to withdraw at any time during the study and withdrawal will not affect my relationship with any of the named organisations and/or research team members;

$\square$ I understand that I can download a copy of this consent form from www.cepar.edu.au.

I agree, tick all box and continue

I do not wish to participate

20

What was your age at your last birthday?

years old 

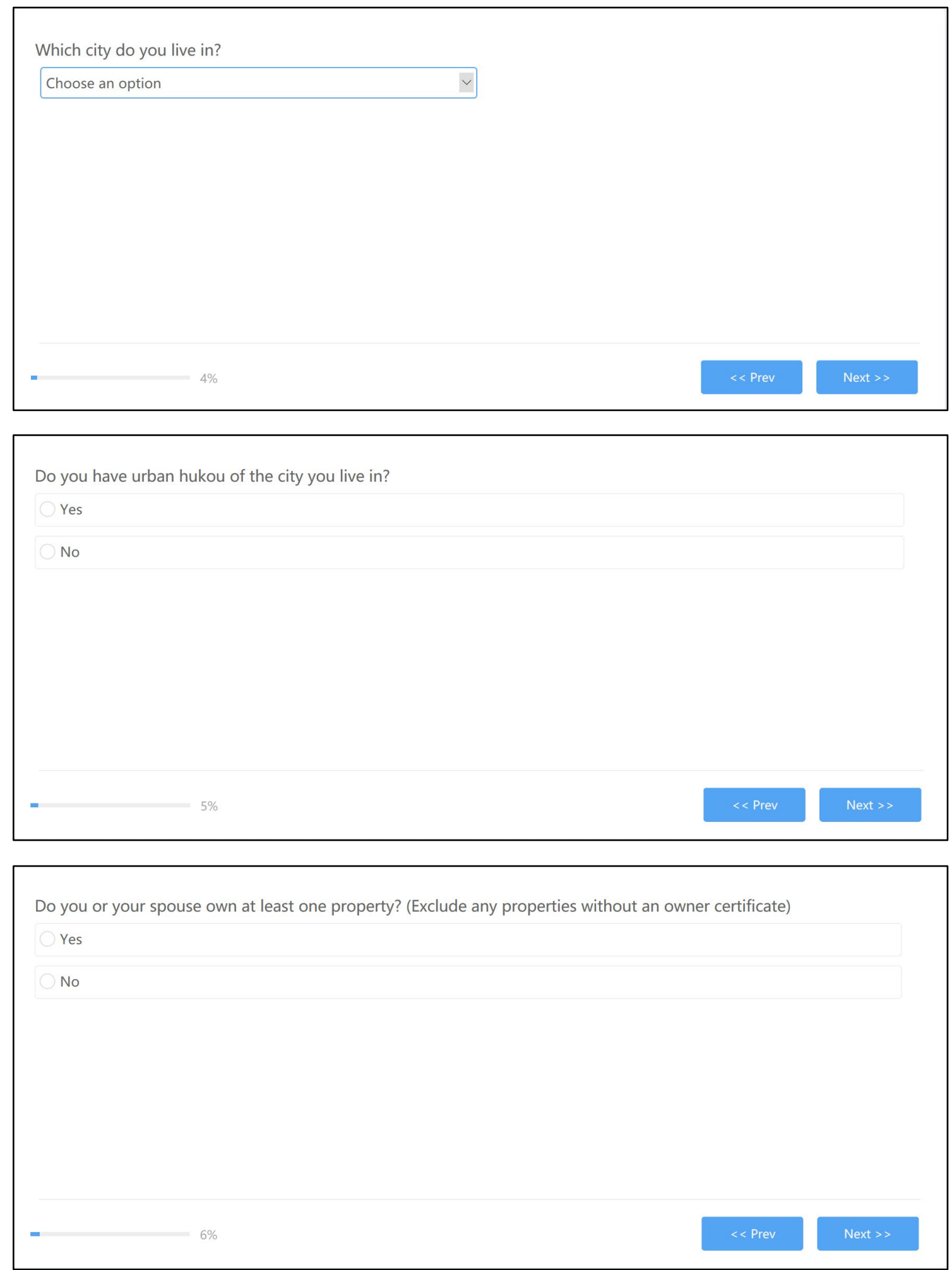

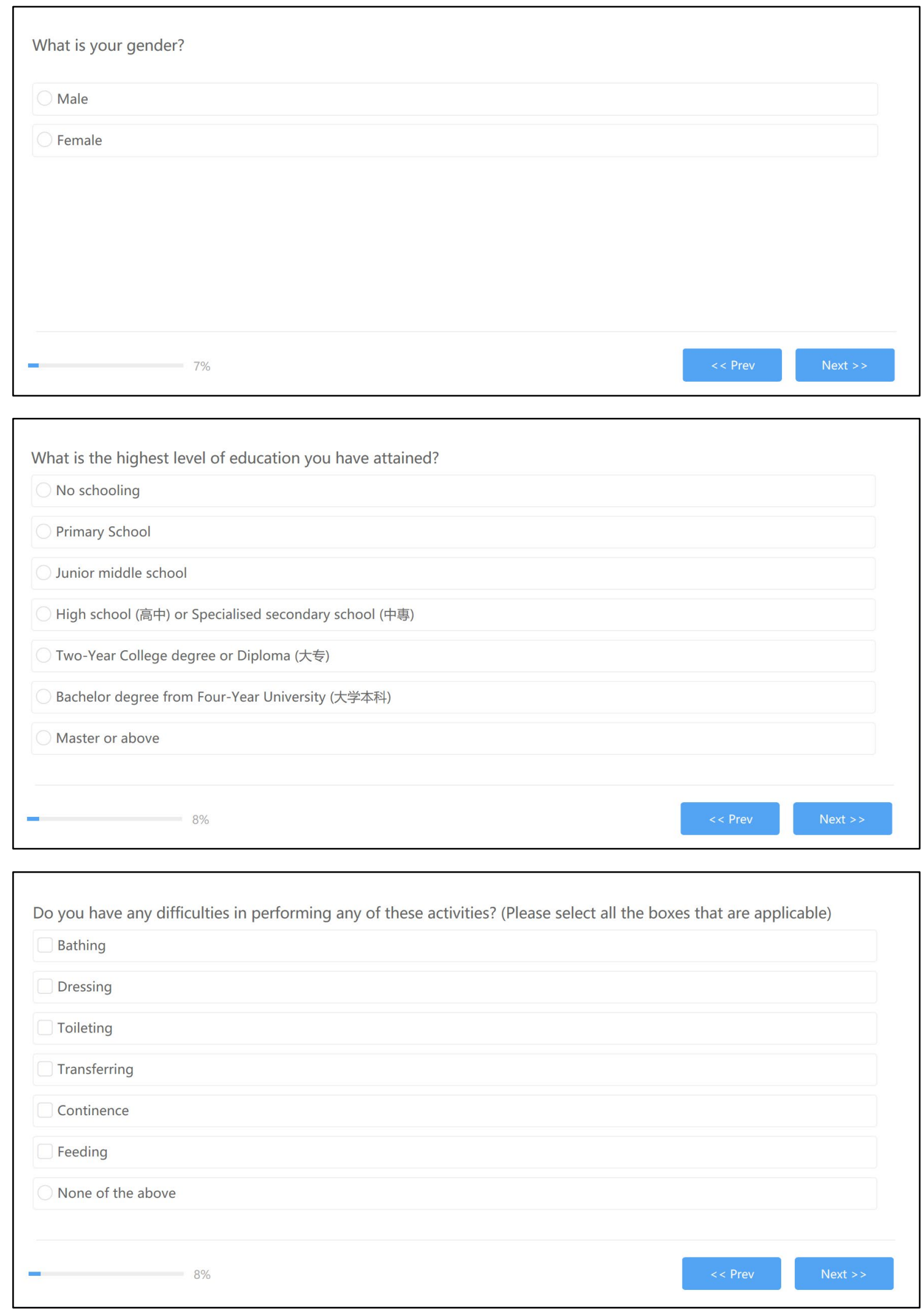


\section{Introductory questions}

\section{Introductory slide}

Thank you for agreeing to participate in this survey about financing long-term care.

Please take as much time as you need to answer the questions. All your answers to the questions are strictly anonymous - that is, no one involved in this study can identify you personally, no one will contact you after the survey and no sales solicitation is involved. Your answers will be used only for academic research.

Please answer each question as honestly as possible. The aim of the survey is to provide a reliable and accurate picture of how people like you feel about the new financial products described in the survey. Please do not use any other sources of information to answer the questions because our research focuses on how you (and others like you) would answer them. Please answer all of the survey questions.

Please DO NOT USE the "back" and "forward" buttons in your browser. Instead, please use the buttons at the bottom of each screen. If you would like to pause the survey to return to it later, simply close the window and click on the original link in the invitation when you are ready to resume. It will return you to the last point of entry in the survey.

- $9 \% \quad$ \& Prev

\section{Introductory questions}

In answering these questions, please exclude any properties for which you do not have an owner certificate (房产证).

Excluding all properties that you own, what is the total value of your household savings (including, for example, saving accounts, term deposits, government bonds, stocks, shares in investment funds)?

RMB 0-50,000

RMB 50,001-500,000

RMB 500,001 or more

Please provide more details about your household savings. Excluding all properties that you own, what is the total value of your household savings (including, for example, saving accounts, term deposits, government bonds, stocks, shares in investment funds)?

RMB 500,001-1,000,000

RMB $1,000,001-1,500,000$

RMB 1,500,001-2,000,000

RMB 2,000,001 or more 

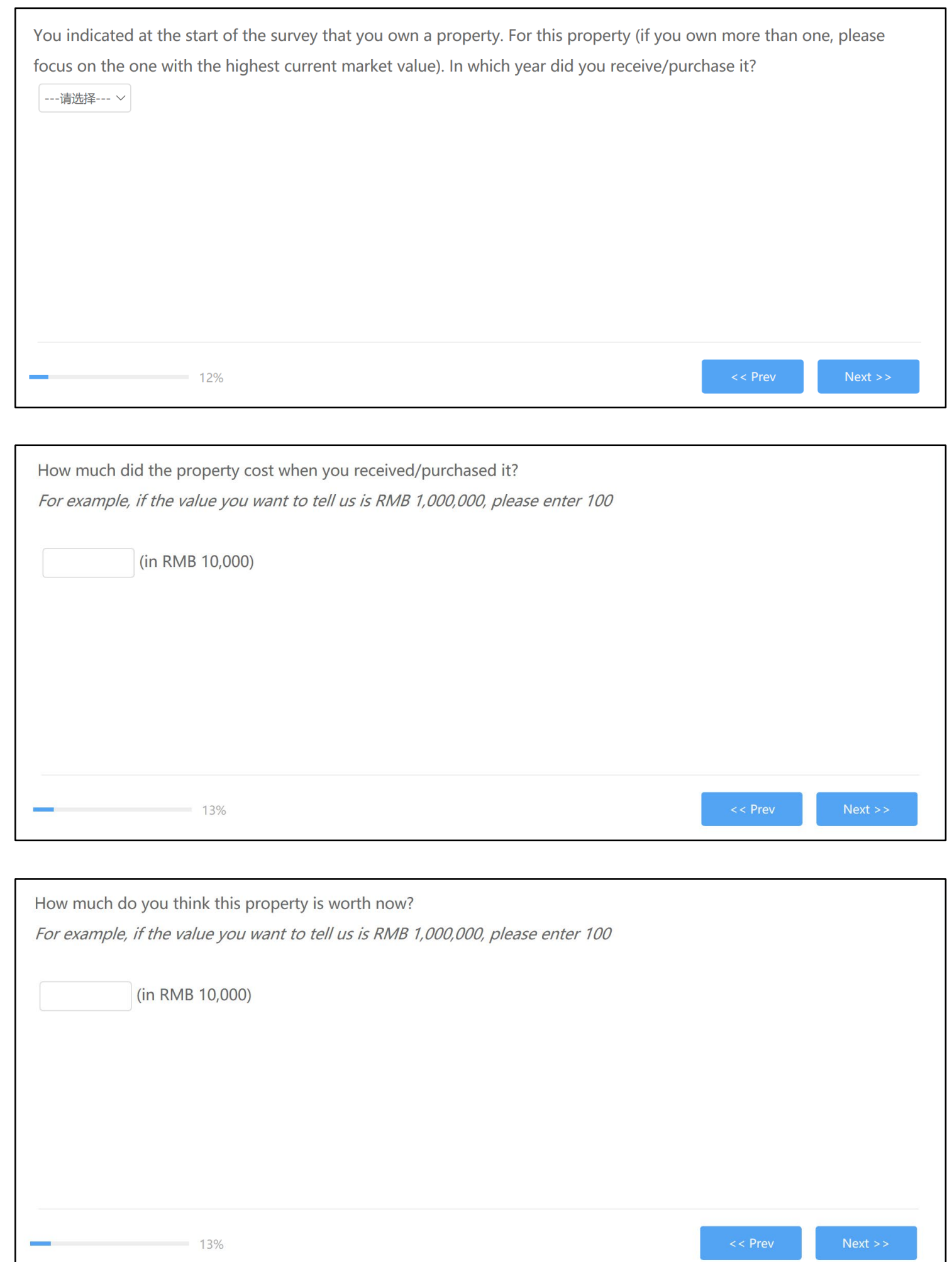


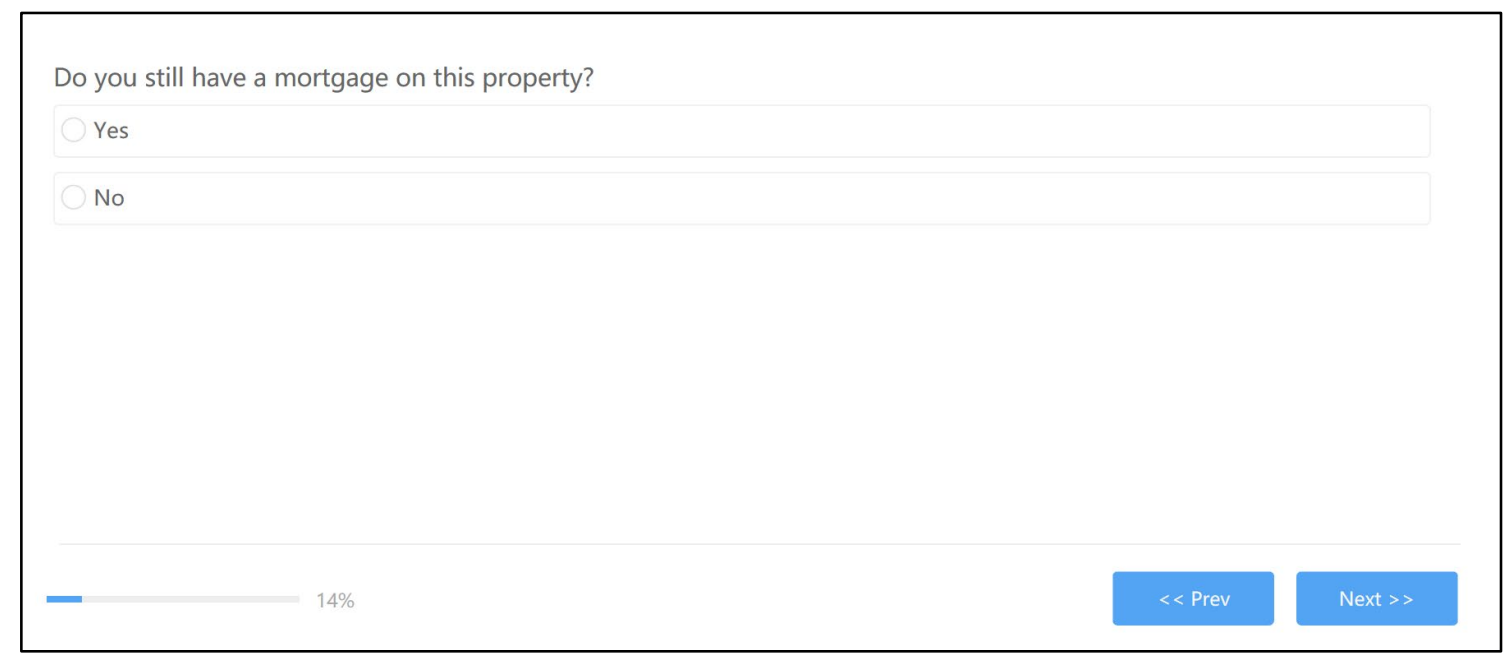

What is the outstanding mortgage loan balance?

For example, if the value you want to tell us is $R M B 1,000,000$, please enter 100

(in RMB 10,000)

-

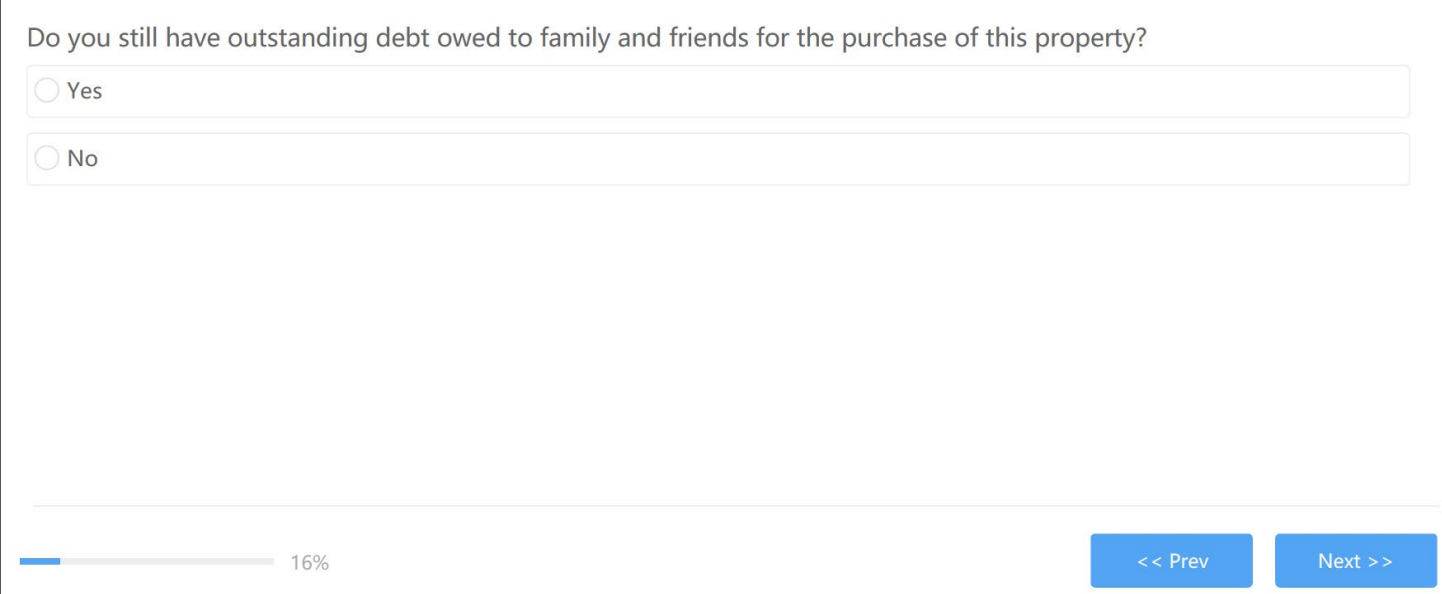


What is the outstanding loan amount from family and friends?

For example, if the value you want to tell us is RMB 1,000,000, please enter 100

(in RMB 10,000)

How many properties do you or your spouse own in total, including the one you just told us about?

r 


\section{Information about LTC and choice tasks}

\section{Facts about health states and long-term care}

Hover your mouse over the blue text for more information.

As people get older, they are more likely to need help with activities of daily living such as bathing or dressing.

In this survey, we refer to an older person as disabled if they need help permanently with three or more of the following six activities of daily living: bathing, dressing, toileting, transferring, continence, or feeding. We refer to this help as longterm care.

We refer to older persons as non-disabled if they only need help with two or less of the six activities of daily living.

On average,

3 out of 10 men aged 60 will eventually become disabled and will need long-term care as they get older, while 4 out of 10 women aged 55 will eventually become disabled and will need long-term care as they get older.

There are two types of long-term care:

Informal care: long-term care provided by the family and/or friends.

Formal care: long-term care provided by professional caring personnel. Formal care in a basic residential nursing home costs about RMB 11,500 per month in today's prices.

When you are disabled, you can receive formal care, informal care or a combination of the two.

Long-term care income refers to the regular monthly income you can receive when you and/or your spouse are disabled and need long-term care.

You can click "> > " to continue after 20 seconds.

New Long-term Care Income Products

In this survey we will ask you to make some choices about three new financial products designed to fund long-term care. Each of these products will provide you with an income when you require long-term care.

For each of the three long-term care income products we will describe the product and show you a case study. We will then ask you to complete a choice task. Finally we will ask you to choose your most preferred and least preferred of the three choices. In total you will complete four (4) choice tasks.

Please read the product descriptions carefully because your understanding will affect the bonus amount that you can earn from the survey. 


\section{Long-term care income choice tasks}

In each of the choice tasks you will be asked you to choose how much long-term care income you would like to buy. Ignoring your own financial circumstances, we want you to imagine that:

- you are aged 60,

- you are married and your spouse is aged 55

- you are about to retire,

- you own your own home in the city you live in, which is currently worth RMB 5,000,000

- you have RMB 750,000 in your savings account,

- you have no other assets. 


\title{
4. Choice tasks
}

\section{Choice task 1}

\author{
Long-term Care Income Product S \\ Hover your mouse over the blue text for more information.
}

We would like to introduce you to Long-term Care Income Product S.

You buy Long-term Care Income Product S with a single payment from your savings account. When you and/or your spouse need long-term care you receive a regular monthly income.

Please read the product description carefully as your product understanding will be tested in a quiz.

The first column lists the product properties. The second column explains these properties for Long-term Care Income Product S.

\begin{tabular}{|c|c|}
\hline Product Properties & Long-term Care Income Product S \\
\hline Who offers this product? & A state-owned bank. \\
\hline $\begin{array}{l}\text { How much do you need to pay at the } \\
\text { start of the contract? }\end{array}$ & $\begin{array}{l}\text { The amount of the single payment you make at the start of } \\
\text { the contract depends on the size of the monthly income } \\
\text { you/your spouse want to receive when you/your spouse need } \\
\text { long-term care. }\end{array}$ \\
\hline $\begin{array}{l}\text { How much long-term care income can } \\
\text { you buy at most? }\end{array}$ & $\begin{array}{l}\text { Depends on: Your age, your spouse's age, your gender; and } \\
\text { the amount you wish to pay at the start of the contract. }\end{array}$ \\
\hline When can you purchase this product? & When you and your spouse are aged 55-65 and non-disabled. \\
\hline What are your benefits? & $\begin{array}{l}\text { You/your spouse receive a monthly income when you/your } \\
\text { spouse are disabled, for as long as you/your spouse are alive. }\end{array}$ \\
\hline How do you receive the income? & $\begin{array}{l}\text { The product provider transfers the income into your savings } \\
\text { account each month. }\end{array}$ \\
\hline $\begin{array}{l}\text { Do you receive any income when you } \\
\text { and your spouse are non-disabled? }\end{array}$ & No. \\
\hline $\begin{array}{l}\text { What happens when one spouse is } \\
\text { disabled, and the other spouse is non- } \\
\text { disabled? }\end{array}$ & $\begin{array}{l}\text { The disabled spouse can choose to move to a residential } \\
\text { nursing home or to stay at home. You can use the monthly } \\
\text { income for any purpose, including but not limited to pay for } \\
\text { formal care or to compensate family members/friends for } \\
\text { informal care. }\end{array}$ \\
\hline $\begin{array}{l}\text { What happens when both spouses are } \\
\text { disabled, or one spouse is disabled, and } \\
\text { the other spouse is deceased? }\end{array}$ & $\begin{array}{l}\text { You/your spouse will need to move to a residential nursing } \\
\text { home. You can use the monthly income for any purpose, } \\
\text { including but not limited to pay for formal care or to } \\
\text { compensate family members/friends for informal care at the } \\
\text { residential nursing home. }\end{array}$ \\
\hline Who will determine your health status? & $\begin{array}{l}\text { You choose a doctor from a list of doctors appointed by the } \\
\text { government. The doctor determines whether you/your spouse } \\
\text { are non-disabled or disabled. Once you/your spouse are } \\
\text { disabled, you/your spouse will be entitled to receive the } \\
\text { monthly income benefits for as long as you/your spouse are } \\
\text { alive. }\end{array}$ \\
\hline $\begin{array}{l}\text { Do you have to make a claim to receive } \\
\text { the monthly income when you need } \\
\text { long-term care? }\end{array}$ & $\begin{array}{l}\text { No. The doctor will inform the product provider to transfer the } \\
\text { monthly income to you. }\end{array}$ \\
\hline When do you pay the product provider? & You make a single payment at the start of the contract. \\
\hline When does the contract terminate? & When you and your spouse pass away. \\
\hline Can you terminate the contract earlier? & $\begin{array}{l}\text { Yes, but you will not receive the regular income if you later } \\
\text { need long-term care. }\end{array}$ \\
\hline
\end{tabular}

You can click ">> " to continue after 20 seconds. 


\section{Case study for Long-term Care Income Product S}

Hover your mouse over the blue text for more information.

Please read the following case study which illustrates how Long-term Care Income Product S works.

Mr. Wang is aged 60 and Mrs. Wang is aged 55 in 2019. They live in their own apartment in Beijing which is worth RMB $5,000,000$ and have RMB 750,000 in their savings account. They decide to buy Long-term Care Income Product S to cover their future long-term care needs.

- They choose to use RMB 200,000 from their savings account to buy long-term care income with Long-term Care Income Product S.

- If one or both are disabled, they will receive a monthly income according to the following table:

\begin{tabular}{|l|l|l|}
\hline Both non-disabled/deceased & 1 non-disabled/deceased, 1 disabled & Both disabled \\
\hline RMB 0/month & RMB 3,514/month & RMB 7,028 /month \\
\hline
\end{tabular}

- The couple fully own their apartment, including all growth in its value, if any.

This contract will terminate when both Mr. and Mrs. Wang pass away.

Assume that Mr. Wang remains non-disabled and passes away in 2044. In the same year, Mrs. Wang becomes disabled and permanently moves into a residential nursing home. She will receive a long-term care income of RMB $3,514 /$ month until she passes away. When she passes away, their daughter inherits the apartment.

How do you rate your understanding of Long-term Care Income Product S?

Completely clear

Mostly clear

Generally clear

Mostly confusing

Completely confusing

You can click " > > to continue after 20 seconds 
Task 1 of 4: Long-term Care Income Product S

Hover your mouse over the blue text for more information

In this choice task, assume you have RMB 750,000 in your savings account and your home is worth RMB 5,000,000. You can use the money in your savings account to purchase long-term care income with Long-term Care Income Product S.

The decision you have to make is:

Would you like to buy long-term care income with Long-term Care Income Product S? And if you do

How much of your savings do you want to use to buy long-term care income?

Use the slider below to indicate your choice. The outcomes of your choice are summarised in the table below.

You can position the slider anywhere on the line, but you need to move it at least once before you can continue. If you

DON' T want to buy Long Term Care Product S place the slider at RMB 0.

$$
\begin{array}{ll}
\text { Long-term Care Income Product S } \square_{\text {RMB } 0} & \text { RMB 750,000 }
\end{array}
$$

\begin{tabular}{|c|c|}
\hline & Outcome \\
\hline $\begin{array}{l}\text { Regular income when you and your spouse } \\
\text { are non-disabled }\end{array}$ & RMB 0 per month \\
\hline $\begin{array}{l}\text { Regular income when one spouse is disabled, } \\
\text { and the other spouse is non-disabled or } \\
\text { deceased }\end{array}$ & $\begin{array}{l}\text { RMB } 0 \text { per month } \\
\text { This would cover } \mathbf{0} \% \text { of the cost of formal care in a residential nursing } \\
\text { home for one person or compensate your family/friends who take care } \\
\text { of you. }\end{array}$ \\
\hline $\begin{array}{l}\text { Regular income when both spouses are } \\
\text { disabled }\end{array}$ & $\begin{array}{l}\text { RMB } 0 \text { per month } \\
\text { This would cover } \mathbf{0 \%} \text { of the cost of formal care in a residential nursing } \\
\text { home for you and your spouse or compensate your family/friends who } \\
\text { take care of you. }\end{array}$ \\
\hline Total payment for long-term care income & Single payment of RMB $\mathbf{0}$ at the start of the contract \\
\hline $\begin{array}{l}\text { Payment for long-term care income from } \\
\text { your savings account }\end{array}$ & Single payment of RMB $\mathbf{0}$ at the start of the contract \\
\hline Remaining money in your savings account & RMB 0 \\
\hline Your remaining housing wealth & RMB 5,000,000 \\
\hline Your remaining total wealth & RMB 0 \\
\hline Additional features: & $\begin{array}{l}\text { You receive the monthly income for as long as you/your spouse are } \\
\text { disabled }\end{array}$ \\
\hline
\end{tabular}

Why did you not purchase more long-term care income with Long-term Care Income Product S? Please only choose the main reason.

I think I can manage long-term care risk.

My children/grandchildren will care for me when I am old.

I think the product is too complex.

I do not think the product is a good deal.

I do not trust the product provider. 
Choice task 2

Long-term Care Income Product $\mathrm{R}$

Hover your mouse over the blue text for more information.

We would like to introduce you to Long-term Care Income Product R.

You buy Long-term Care Income Product R by borrowing against your home. When you and/or your spouse need long term care, you receive a regular monthly income.

Please read the product description carefully as your product understanding will be tested in a quiz.

The first column lists the product properties. The second column explains these properties for Long-term Care Income Product R.

\begin{tabular}{|c|c|}
\hline & Long-term Care Income Product $\mathbf{R}$ \\
\hline Who offers this product? & A state-owned bank. \\
\hline \multicolumn{2}{|c|}{ Product properties when you are alive } \\
\hline $\begin{array}{l}\text { How much do you need to pay } \\
\text { at the start of the contract? }\end{array}$ & No payments required. \\
\hline $\begin{array}{l}\text { Is your home used as a } \\
\text { collateral? }\end{array}$ & Yes. \\
\hline $\begin{array}{l}\text { Can you continue to live in your } \\
\text { home? }\end{array}$ & $\begin{array}{l}\text { Yes. You and your spouse have a guaranteed right to live in your home } \\
\text { while at least one of you is non-disabled. }\end{array}$ \\
\hline $\begin{array}{l}\text { Do you retain the full legal right } \\
\text { of your home }\end{array}$ & Yes. For example, you can rent out your home. \\
\hline $\begin{array}{l}\text { How much long-term care } \\
\text { income can you buy at most? }\end{array}$ & $\begin{array}{l}\text { Depends on: Your age, your spouse's age, your gender, the amount } \\
\text { you wish to pay at the start of the contract and the value of your home } \\
\text { at the start of the contract }\end{array}$ \\
\hline $\begin{array}{l}\text { How is the home value } \\
\text { assessed? }\end{array}$ & $\begin{array}{l}\text { The value of your home is assessed by an independent, authorized } \\
\text { appraiser. }\end{array}$ \\
\hline $\begin{array}{l}\text { When can you purchase this } \\
\text { product? }\end{array}$ & When you and your spouse are aged 55-65 and non-disabled. \\
\hline What are your benefits? & $\begin{array}{l}\text { You/your spouse receive a monthly income when you/your spouse are } \\
\text { disabled, for as long as you/your spouse are alive. }\end{array}$ \\
\hline How do you receive the income? & $\begin{array}{l}\text { The product provider transfers the income into your savings } \\
\text { account each month. }\end{array}$ \\
\hline $\begin{array}{l}\text { Do you receive any income when } \\
\text { you and your spouse are non- } \\
\text { disabled? }\end{array}$ & No. \\
\hline $\begin{array}{l}\text { What happens when one spouse } \\
\text { is disabled, and the other spouse } \\
\text { is non-disabled? }\end{array}$ & $\begin{array}{l}\text { The disabled spouse can choose to move to a residential nursing } \\
\text { home or to stay at home. You can use the monthly income for any } \\
\text { purpose, including but not limited to pay for formal care or to } \\
\text { compensate family members/friends for informal care. }\end{array}$ \\
\hline $\begin{array}{l}\text { What happens when both } \\
\text { spouses are disabled, or one } \\
\text { spouse is disabled, and the other } \\
\text { spouse is deceased? }\end{array}$ & $\begin{array}{l}\text { You/your spouse will need to move to a residential nursing home. You } \\
\text { can use the monthly income for any purpose, including but not } \\
\text { limited to pay for formal care or to compensate family } \\
\text { members/friends for informal care at the residential nursing home. }\end{array}$ \\
\hline $\begin{array}{l}\text { Who will determine your health } \\
\text { status? }\end{array}$ & $\begin{array}{l}\text { You choose a doctor from a list of doctors appointed by the } \\
\text { government. The doctor determines whether you/your spouse are } \\
\text { non-disabled or disabled. Once you/your spouse are disabled, } \\
\text { you/your spouse will be entitled to receive the monthly income } \\
\text { benefits for as long as you/your spouse are alive. }\end{array}$ \\
\hline \begin{tabular}{|l|} 
Do you have to make a claim to \\
receive the monthly income \\
when you need long-term care?
\end{tabular} & $\begin{array}{l}\text { No. The doctor will inform the product provider to transfer the } \\
\text { monthly income to you. }\end{array}$ \\
\hline Will this product incur any loan? & $\begin{array}{l}\text { Yes, but no repayments are required while you/your spouse live in } \\
\text { your home. }\end{array}$ \\
\hline What is the debt amount? & $\begin{array}{l}\text { The cost of the long-term care income becomes a debt which } \\
\text { accumulates interest. }\end{array}$ \\
\hline $\begin{array}{l}\text { What is the interest rate on the } \\
\text { loan? }\end{array}$ & $5.80 \%$ p.a. Set by the government. Fixed at the start of the contract. \\
\hline $\begin{array}{l}\text { Can you terminate the contract } \\
\text { earlier? }\end{array}$ & Yes, you can. \\
\hline \begin{tabular}{|l|} 
What do you need to do to \\
terminate the contract earlier?
\end{tabular} & Repay the loan \\
\hline \multicolumn{2}{|c|}{ Product properties when both of you are deceased/move to a residential nursing home } \\
\hline $\begin{array}{l}\text { What happens after you and } \\
\text { your spouse have both passed } \\
\text { away or moved into a residential } \\
\text { nursing home? }\end{array}$ & $\begin{array}{l}\text { The product provider will sell your property at the highest possible } \\
\text { market price. }\end{array}$ \\
\hline $\begin{array}{l}\text { What happens to the sale } \\
\text { proceeds? }\end{array}$ & $\begin{array}{l}\text { The sale proceeds are used to repay the loan. If the sale proceeds } \\
\text { exceed the loan amount, you/your spouse/your heirs can retain the } \\
\text { difference. If the sale proceeds are insufficient to cover the debt, } \\
\text { you/your spouse/your heirs are not required to make an extra payment. }\end{array}$ \\
\hline $\begin{array}{l}\text { Can your heirs remain in the } \\
\text { property when you and your } \\
\text { spouse pass away? }\end{array}$ & $\begin{array}{l}\text { Yes. Your heirs have the option to repay the debt and keep your } \\
\text { home. }\end{array}$ \\
\hline $\begin{array}{l}\text { When does the contract } \\
\text { terminate? }\end{array}$ & When you and your spouse are deceased. \\
\hline
\end{tabular}

You can click "> >" to continue after 20 seconds. 
Case study for Long-term Care Income Product $\mathrm{R}$

Hover your mouse over the blue text for more information.

Please read the following case study which illustrates how Long-term Care Income Product R works.

Mr. Wang is aged 60 and Mrs. Wang is aged 55 in 2019. They have an adult daughter. They live in their own apartment in Beijing which is worth RMB 5,000,000 and have RMB 750,000 in their savings account. They decide to buy Long-term Care Income Product $\mathrm{R}$ to cover their future long-term care needs.

- They choose to borrow RMB 600,000 against their apartment to buy long-term care income with Long-term Care

Income Product R. The amount becomes a debt which accumulates interest at the fixed interest rate of $5.8 \%$ p.a

- If one or both are disabled, they will receive a monthly income according to the following table:

\begin{tabular}{|l|l|l|}
\hline Both non-disabled/deceased & 1 non-disabled/deceased, 1 disabled & Both disabled \\
\hline RMB 0/month & RMB 10.542/month & RMB 21,085/month \\
\hline
\end{tabular}

- They do not have to repay anything while at least one of them still lives at home.

- The couple fully own their apartment, including all growth in its value, if any.

This contract will terminate when both Mr. and Mrs. Wang pass away.

Assume that Mr. Wang remains non-disabled and passes away in 2044. In the same year, Mrs. Wang becomes disabled and permanently moves into a residential nursing home. The outstanding debt amount in 2044 accumulated from the initial loan is RMB $2,456,000$. Below are three possible scenarios in 2044:

- Scenario A: The product provider sells the home at the highest possible market price of RMB 10,000,000. The sale proceeds are used to repay the debt. Mrs. Wang receives the remaining RMB 7,544,000. She will receive a long-term care income of RMB 10,542/month until she passes away.

- Scenario B: The product provider sells the home at the highest possible market price of only RMB 1,000,000. All sale proceeds are used to repay the debt. Mrs. Wang will receive nothing from the sale, but she is not required to make an extra payment. The difference is a loss to the product provider. Mrs. Wang will receive a long-term care income of RMB $10.542 /$ month until she passes away.

- Scenario C: Their daughter decides to repay the debt herself and keep their property. Mrs. Wang will receive a longterm care income of RMB 10,542/month until she passes away.

How do you rate your understanding of Long-term Care Income Product R?

Completely clear

Mostly clear

Generally clear

Mostly confusing

Completely confusing

You can click ">> " to continue after 20 seconds. 
Task 2 of 4: Long-term Care Income Product $\mathrm{R}$

Hover your mouse over the blue text for more information.

In this choice task, assume, you have RMB 750,000 in your savings account and your home is worth RMB 5,000,000. You can use the money in your savings account to purchase long-term care income with Long-term Care Income Product $S$. You can also borrow against your home to purchase long-term care income with Long-term Care Income Product R.

Use the two sliders below to indicate your choices. You can buy long-term care income with your savings (Long-term Care Income Product S) and/or borrow against your home (Long-term Care Income Product R). The outcomes of your

choice are summarised in the table below.

The decisions you have to make are:

Would you like to buy long-term care income? And if you do

MRa. How much of your savings do you want to use to buy long-term care income with Long-term Care Income Product S?

You can position the slider anywhere on the line, but you need to move it at least once before you can continue. If you DON' T want to buy Long Term Care Product S place the slider at RMB 0.

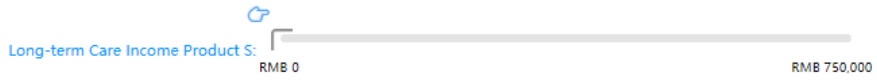

MRb. How much do you want to borrow against your home to buy long-term care income with Long-term Care Income Product R?

You can position the slider anywhere on the line, but you need to move it at least once before you can continue. If you DON' T want to buy Long Term Care Product R place the slider at RMB 0.

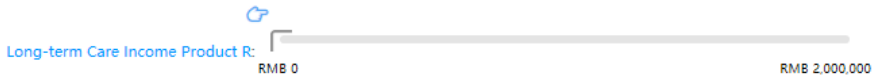

\begin{tabular}{|l|l|}
\hline $\begin{array}{l}\text { Regular income when you and your spouse } \\
\text { are non-disabled }\end{array}$ & Outcome \\
\hline $\begin{array}{l}\text { Regular income when one spouse is } \\
\text { disabled, and the other spouse is non- } \\
\text { disabled or deceased }\end{array}$ & $\begin{array}{l}\text { RMB 0 per month } \\
\text { This would cover } \mathbf{0 . 0 0 \%} \text { of the cost of formal care in a } \\
\text { residential nursing home for one person or compensate your } \\
\text { family/friends who take care of you. }\end{array}$ \\
\hline $\begin{array}{l}\text { Regular income when both spouses are } \\
\text { disabled }\end{array}$ & $\begin{array}{l}\text { RMB 0 per month } \\
\text { This would cover } \mathbf{0 . 0 0 \%} \text { of the cost of formal care in a } \\
\text { residential nursing home for you and your spouse or } \\
\text { compensate your family/friends who take care of you. }\end{array}$ \\
\hline $\begin{array}{l}\text { Total payment for long-term care income } \\
\text { Payment for long-term care income from } \\
\text { your savings account }\end{array}$ & RMB 0 \\
\hline $\begin{array}{l}\text { Payment for long-term care income } \\
\text { from Long-term Care Income Product R }\end{array}$ & RMB 0 \\
\hline Remaining money in your savings account & RMB 0 loan with annual interest rate 5.80\% p.a. \\
\hline Your remaining housing wealth & RMB 0 \\
\hline Your remaining total wealth & RMB 0 \\
\hline Additional features: & $\begin{array}{l}\text { You receive the monthly income for as long as you/your spouse } \\
\text { are disabled }\end{array}$ \\
\hline
\end{tabular}

Why did you not purchase more of Long-term Care Income Product R to pay for the long-term care income? Please only choose the main reason.

I think I can manage long-term care risk.

My children/grandchildren will care for me when I am old.

I think the product is too complex.

I do not think the product is a good deal.

I do not trust the product provider.

I do not want to have a (higher) loan.

I am worried that I would be evicted from my property. 


\section{Choice task 3}

Long-term Care Income Product H

Hover your mouse over the blue text for more information.

We would like to introduce you to Long-term Care Income Product $\mathrm{H}$.

You buy Long-term Care Income Product $\mathrm{H}$ by selling part of your home. When you and/or your spouse need long-term care, you receive a regular monthly income.

Please read the product description carefully as your product understanding will be tested in a quiz.

The first column lists the product properties. The second column explains these properties for Long-term Care Income Product $\mathrm{H}$.

\begin{tabular}{|c|c|}
\hline & Long-term Care Income Product H \\
\hline Who offers this product? & A state-owned bank. \\
\hline \multicolumn{2}{|c|}{ Product properties when you are alive } \\
\hline $\begin{array}{l}\text { How much do you need to pay } \\
\text { at the start of the contract? }\end{array}$ & No payments required. \\
\hline $\begin{array}{l}\text { Is your home used as a } \\
\text { collateral? }\end{array}$ & No, a part of your home is sold to the product provider. \\
\hline $\begin{array}{l}\text { Can you continue to live in your } \\
\text { home? }\end{array}$ & $\begin{array}{l}\text { Yes. You and your spouse have a guaranteed right to live in your home } \\
\text { while at least one of you is non-disabled. }\end{array}$ \\
\hline $\begin{array}{l}\text { Do you retain the full legal right } \\
\text { of your home }\end{array}$ & No, but you can still rent out your home. \\
\hline $\begin{array}{l}\text { How much long-term care } \\
\text { income can you buy at most? }\end{array}$ & $\begin{array}{l}\text { Depends on: Your age, your spouse's age, your gender, the amount } \\
\text { you wish to pay at the start of the contract and the value of your home } \\
\text { at the start of the contract }\end{array}$ \\
\hline $\begin{array}{l}\text { How is the home value } \\
\text { assessed? }\end{array}$ & $\begin{array}{l}\text { The value of your home is assessed by an independent, authorized } \\
\text { appraiser. }\end{array}$ \\
\hline $\begin{array}{l}\text { When can you purchase this } \\
\text { product? }\end{array}$ & When you and your spouse are aged 55-65 and non-disabled. \\
\hline What are your benefits? & $\begin{array}{l}\text { You/your spouse receive a monthly income when you/your spouse are } \\
\text { disabled, for as long as you/your spouse are alive. }\end{array}$ \\
\hline How do you receive the income? & $\begin{array}{l}\text { The product provider transfers the income into your savings } \\
\text { account each month. }\end{array}$ \\
\hline $\begin{array}{l}\text { Do you receive any income when } \\
\text { you and your spouse are non- } \\
\text { disabled? }\end{array}$ & No. \\
\hline \begin{tabular}{|l|} 
What happens when one spouse \\
is disabled, and the other spouse \\
is non-disabled?
\end{tabular} & $\begin{array}{l}\text { The disabled spouse can choose to move to a residential nursing } \\
\text { home or to stay at home. You can use the monthly income for any } \\
\text { purpose, including but not limited to pay for formal care or to } \\
\text { compensate family members/friends for informal care. }\end{array}$ \\
\hline $\begin{array}{l}\text { What happens when both } \\
\text { spouses are disabled, or one } \\
\text { spouse is disabled, and the other } \\
\text { spouse is deceased? }\end{array}$ & $\begin{array}{l}\text { You/your spouse will need to move to a residential nursing home. You } \\
\text { can use the monthly income for any purpose, including but not } \\
\text { limited to pay for formal care or to compensate family } \\
\text { members/friends for informal care at the residential nursing home. }\end{array}$ \\
\hline \begin{tabular}{|l|}
$\begin{array}{l}\text { Who will determine your health } \\
\text { status? }\end{array}$ \\
\end{tabular} & $\begin{array}{l}\text { You choose a doctor from a list of doctors appointed by the } \\
\text { government. The doctor determines whether you/your spouse are } \\
\text { non-disabled or disabled. Once you/your spouse are disabled, } \\
\text { you/your spouse will be entitled to receive the monthly income } \\
\text { benefits for as long as you/your spouse are alive. }\end{array}$ \\
\hline \begin{tabular}{|l|} 
Do you have to make a claim to \\
receive the monthly income \\
when you need long-term care?
\end{tabular} & $\begin{array}{l}\text { No. The doctor will inform the product provider to transfer the } \\
\text { monthly income to you. }\end{array}$ \\
\hline $\begin{array}{l}\text { Can you terminate the contract } \\
\text { earlier? }\end{array}$ & Yes, you can. \\
\hline $\begin{array}{l}\text { What do you need to do to } \\
\text { terminate the contract earlier? }\end{array}$ & Buy back the proportion you sold to the product provider \\
\hline \multicolumn{2}{|c|}{ Product properties when both of you are deceased/move to a residential nursing home } \\
\hline $\begin{array}{l}\text { What happens after you and } \\
\text { your spouse have both passed } \\
\text { away or moved into a residential } \\
\text { nursing home? }\end{array}$ & $\begin{array}{l}\text { The product provider will sell your property at the highest possible } \\
\text { market price. }\end{array}$ \\
\hline $\begin{array}{l}\text { What happens to the sale } \\
\text { proceeds? }\end{array}$ & $\begin{array}{l}\text { The sale proceeds are split into two parts. The product provider } \\
\text { keeps the sale proceeds of the proportion you sold. You/your } \\
\text { spouse/your heirs receive the sale proceeds from the proportion you } \\
\text { own. }\end{array}$ \\
\hline $\begin{array}{l}\text { Can your heirs remain in the } \\
\text { property when you and your } \\
\text { spouse pass away? }\end{array}$ & $\begin{array}{l}\text { Yes. Your heirs have the option to buy back the proportion you sold } \\
\text { and keep your home. }\end{array}$ \\
\hline $\begin{array}{l}\text { When does the contract } \\
\text { terminate? }\end{array}$ & When you and your spouse are deceased. \\
\hline
\end{tabular}

You can click ">>" to continue after 20 seconds. 
Case study for Long-term Care Income Product $\mathrm{H}$

Hover your mouse over the blue text for more information.

Please read the following case study which illustrates how Long-term Care Income Product H works.

Mr. Wang is aged 60 and Mrs. Wang is aged 55 in 2019. They have an adult daughter. They live in their own apartment in Beijing which is worth RMB 5,000,000 and have RMB 750,000 in their savings account. They decide to buy Long-term Care Income Product $\mathrm{H}$ to cover their future long-term care needs.

- They choose to sell RMB 2,044,000 of their apartment to buy long-term care income with Long-term Care Income Product $\mathrm{H}$

- If one or both are disabled, they will receive a monthly income according to the following table:

\begin{tabular}{|l|l|l|}
\hline Both non-disabled/deceased & 1 non-disabled/deceased, 1 disabled & Both disabled \\
\hline RMB 0/month & RMB 10,542/month & RMB 21,085/month \\
\hline
\end{tabular}

- They do not have to pay anything while at least one of them still lives at home.

- They still own a part of the apartment.

This contract will terminate when both Mr. and Mrs. Wang pass away.

Assume that Mr. Wang remains non-disabled and passes away in 2044. In the same year, Mrs. Wang becomes disabled and permanently moves into a residential nursing home. Below are three possible scenarios in 2044:

- Scenario A: The product provider sells the home at the highest possible market price of RMB 10,000,000. Mrs. Wang receives $\mathrm{RMB} 5,912,000$ from the sale proceeds. She will receive a long-term care income of RMB 10,542/month until she passes away.

- Scenario B: The product provider sells the home at the highest possible market price of only RMB 1,000,000. Mrs.

Wang receives RMB 591,000 from the sale proceeds. Mrs. Wang will receive a long-term care income of RMB

$10,542 /$ month until she passes away.

- Scenario C: Their daughter decides to buy back and keep their property. Mrs. Wang will receive a long-term care income of RMB 10,542/month until she passes away.

How do you rate your understanding of Long-term Care Income Product H?

Completely clear

Mostly clear

Generally clear

Mostly confusing

Completely confusing

You can click ">> "to continue after 20 seconds. 
Task 3 of 4: Long-term Care Income Product $\mathrm{H}$

Hover your mouse over the blue text for more information.

In this choice task, assume, you have RMB 750,000 in your savings account and your home is worth RMB 5,000,000. You can use the money in your savings account to purchase long-term care income with Long-term Care Income Product $S$. You can also borrow against your home to purchase long-term care income with Long-term Care Income Product $\mathrm{H}$.

Use the two sliders below to indicate your choices. You can buy long-term care income with your savings (Long-term Care Income Product S) and/or borrow against your home (Long-term Care Income Product H). The outcomes of you choice are summarised in the table below.

The decisions you have to make are:

Would you like to buy long-term care income? And if you do

MHa.How much of your savings do you want to use to buy long-term care income with Long-term Care Income Product S?

You can position the slider anywhere on the line, but you need to move it at least once before you can continue. If you DON' T want to buy Long Term Care Product S place the slider at RMB 0.

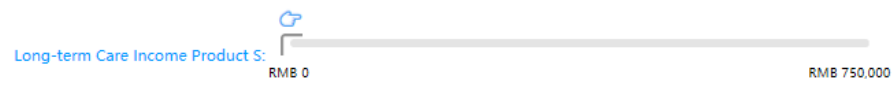

MHb.How much of your home do you want to sell to buy long-term care income with Long-term Care Income Product H?

You can position the slider anywhere on the line, but you need to move it at least once before you can continue. If you DON' T want to buy Long Term Care Product $\mathrm{H}$ place the slider at RMB 0.

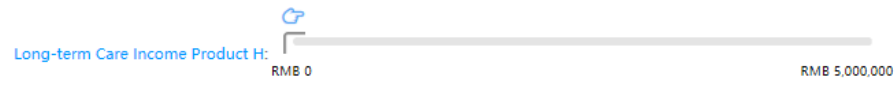

\begin{tabular}{|c|c|}
\hline & Outcome \\
\hline $\begin{array}{l}\text { Regular income when you and your spouse } \\
\text { are non-disabled }\end{array}$ & RMB 0 per month \\
\hline $\begin{array}{l}\text { Regular income when one spouse is } \\
\text { disabled, and the other spouse is non- } \\
\text { disabled or deceased }\end{array}$ & $\begin{array}{l}\text { RMB } 0 \text { per month } \\
\text { This would cover } 0.00 \% \text { of the cost of formal care in a } \\
\text { residential nursing home for one person or compensate your } \\
\text { family/friends who take care of you. }\end{array}$ \\
\hline $\begin{array}{l}\text { Regular income when both spouses are } \\
\text { disabled }\end{array}$ & $\begin{array}{l}\text { RMB } 0 \text { per month } \\
\text { This would cover } \mathbf{0 . 0 0 \%} \text { of the cost of formal care in a } \\
\text { residential nursing home for you and your spouse or } \\
\text { compensate your family/friends who take care of you. }\end{array}$ \\
\hline Total payment for long-term care income & RMB 0 \\
\hline $\begin{array}{l}\text { Payment for long-term care income from } \\
\text { your savings account }\end{array}$ & RMB 0 \\
\hline $\begin{array}{l}\text { Payment for long-term care income } \\
\text { from Long-term Care Income Product } \mathrm{H}\end{array}$ & RMB $\mathbf{0}$ is sold \\
\hline Remaining money in your savings account & RMB 0 \\
\hline Your remaining housing wealth & RMB 0 \\
\hline Your remaining total wealth & RMB 0 \\
\hline Additional features: & $\begin{array}{l}\text { You receive the monthly income for as long as you/your spouse } \\
\text { are disabled }\end{array}$ \\
\hline
\end{tabular}

Why did you not purchase more of Long-term Care Income Product $\mathrm{H}$ to pay for the long-term care income? Please only choose the main reason.

I think I can manage long-term care risk.

My children/grandchildren will care for me when I am old.

I think the product is too complex.

I do not think the product is a good deal.

I do not trust the product provider.

I do not want to sell (more) part of the property.

I am worried that I would be evicted from my property. 


\section{Choice task 4}

\section{Task 4 of 4: Which of the following choices do you prefer?}

Hover your mouse over the blue text for more information.

The following table summarises the three choices you have just made to buy long-term care income. We now ask you to choose which of the three choices would be BEST for you and which of the three choices would be WORST for you.

\section{Product Properties}

Regular income when you and your spouse are non-disa bled

Regular income when one spouse is disabled and the ot her spouse is non-disabled or deceased

Regular income when both spouses are disabled

Total payment for long-term care income

Payment for long-term care income from your savings ac count

Payment for long-term care income from Long-term Care Income Product R

Value of home sold through Long-term Care Income Prod uct $\mathrm{H}$

Remaining money in your savings account Your remaining housing wealth

Your remaining total wealth

Additional comments:

Which one of $A, B$ or $C$ would be BEST for you?

Which one of $A, B$ or C would be WORST for you?

\begin{tabular}{|c|c|c|}
\hline $\begin{array}{c}\text { A } \\
\text { Task } 1 \text { choice } \\
\text { Long-term Care Income Pr } \\
\text { oduct S }\end{array}$ & $\begin{array}{c}\text { B } \\
\text { Task } 2 \text { choice } \\
\text { Long-term Care Income Pr } \\
\text { oduct } \mathrm{R}\end{array}$ & $\begin{array}{c}\mathrm{C} \\
\text { Task } 3 \text { choice } \\
\text { Long-term Care Income } \mathrm{Pr} \\
\text { oduct } \mathrm{H}\end{array}$ \\
\hline \multicolumn{3}{|c|}{0 per month } \\
\hline RMB 1,757 per month & RMB 4,393 per month & RMB 2,508 per month \\
\hline RMB 3,514 per month & RMB 8,786 per month & RMB 5,016 per month \\
\hline $\begin{array}{c}\text { Single payment of RMB } 100, \\
000 \text { at the beginning of the } \\
\text { contract }\end{array}$ & RMB 250,000 & RMB 142,734 \\
\hline RMB 100,000 & RMB 50,000 & RMB 40,000 \\
\hline Not applicable & $\begin{array}{l}\text { RMB } 200,000 \text { loan with annu } \\
\text { al interest rate } 5.8 \% \text { p.a. }\end{array}$ & Not applicable \\
\hline Not applicable & Not applicable & RMB 350,000 is sold \\
\hline RMB 650,000 & RMB 700,000 & RMB 710,000 \\
\hline RMB $5,000,000$ & RMB $5,000,000$ & RMB $4,650,000$ \\
\hline RMB $5,650,000$ & RMB $5,700,000$ & RMB $5,360,000$ \\
\hline
\end{tabular}

You receive the monthly income for as long as you/your spouse are disabled 


\section{Product quiz}

\section{Product knowledge}

Hover your mouse over the blue text for more information.

Now we would like to review your knowledge of the three Long-term Care Income Products.

Which of the following statement(s) apply to each of the products -Long-term Care Income Product S, R and H? Please tick the boxes to indicate to which product or products a statement applies. Your bonus payment depends on the number of correct answers in this quiz. Scores are awarded for each correct answer.

\begin{tabular}{|c|c|c|}
\hline $\begin{array}{l}\text { Long-term Care } \\
\text { Income Product } \\
\text { S }\end{array}$ & $\begin{array}{c}\text { Long-term Care } \\
\text { Income Product } \\
\text { R }\end{array}$ & $\begin{array}{c}\text { Long-term Care } \\
\text { Income Product } \\
\text { H }\end{array}$ \\
\hline & & \\
\hline & & \\
\hline & & \\
\hline & & \\
\hline & & \\
\hline & & \\
\hline & & \\
\hline & & \\
\hline
\end{tabular}

You can receive a monthly income as long as you are alive, even when you re non-disabled.

You pay a lump sum but nothing else at the start of the contract to purchase this product.

You can use the income from the product to compensate your family/friends who take care of you

At the end of the contract, if the house price is higher than the loan amount, you (or your heirs) can receive the difference between the house price and I oan amount.

At the end of the contract, you (or your heirs) will receive a percentage from the sale of the residential property.

The interest rate charged in this contract is fixed during the term of the cont ract.

At the start of the contract, you will need to choose the percentage of your property to sell.

At the end of the contract, you/your spouse/your heirs will have a chance of receiving nothing when your property is sold.

You have 24 correct answers out of 24 


\section{Covariates questions}

You have now completed the choice tasks. Next we will ask you three sets of standard survey questions on:

1.Demographics and health

2.Financial competence and retirement planning

3.Preferences and expectations

1.Demographics and health

The next set of questions with cover employment, marital status, children, income and debt

Which of the following best describes your current employment situation?

Employed by someone else

Self-employed

Unemployed including structurally unemployed (Xia Gang)

Retired

Not in the labour force - stay-at-home parent or caregiver

Not in the labour force - other reasons 


\section{Demographics and health}

Who are you working for? If you are retired or not in the labour force, please answer according to your most recent previous job.

Government (政府机构)

Public institution (事业单位)

Non-government organisation (非政府组织, 社团, 协会, 学会, 等等)

State-owned enterprise (国有企业)

Private company including foreign firm (私营企业，包括外资企业)

Individual firm and freelancer (个体户)

Farmer (农户)

Never worked

Other

\section{Demographics and health}

What is your marital status?

Never married

Married (including living in a long-term partnership)

Divorced

Separated

Widowed

1.Demographics and health

What is your spouse's age? Answer:

years 


\section{Demographics and health}
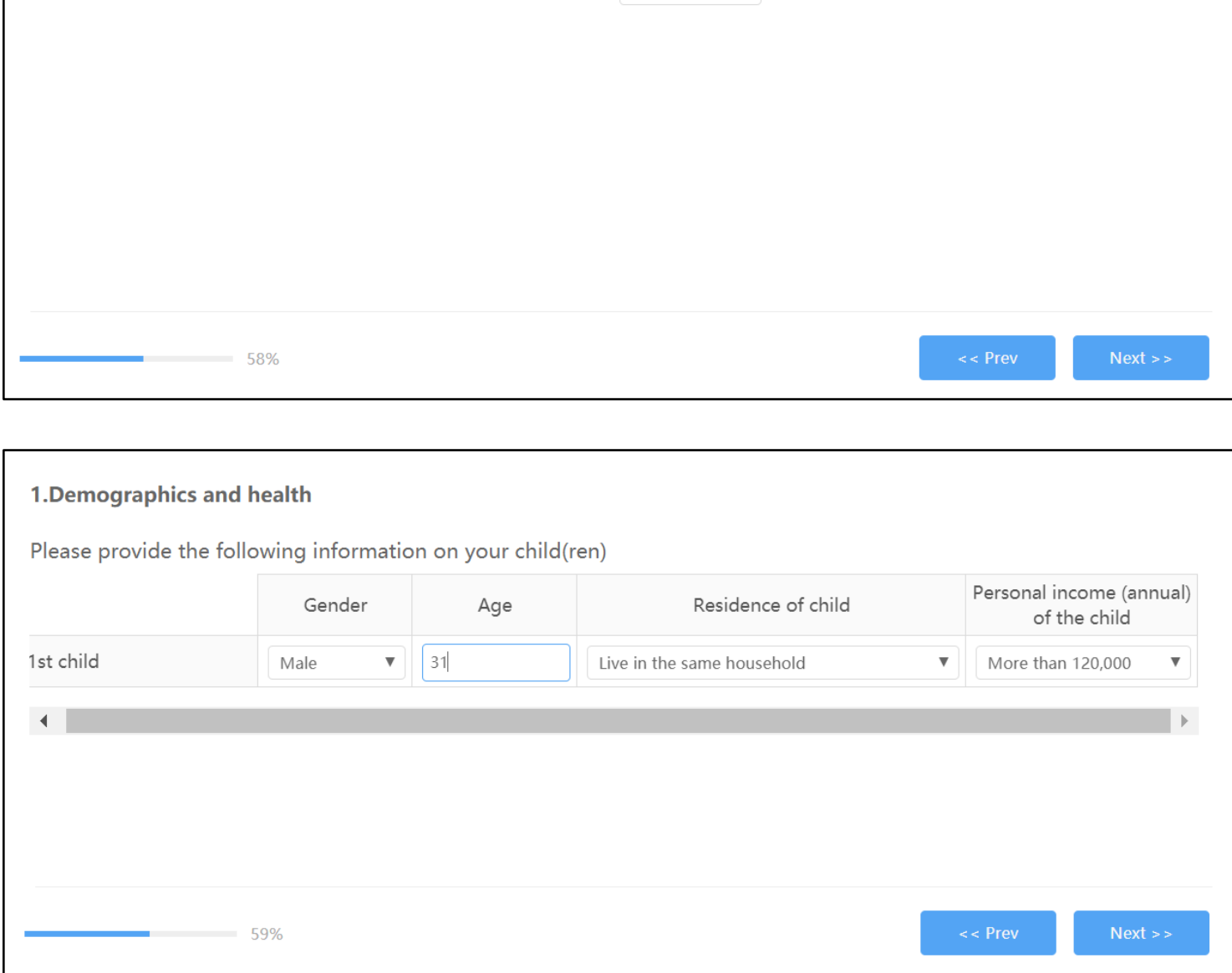

\section{Demographics and health}

How many grandchildren do you have that are still alive? Answer: grandchildren 


\section{Demographics and health}

Please provide the following information on your grandchild(ren)

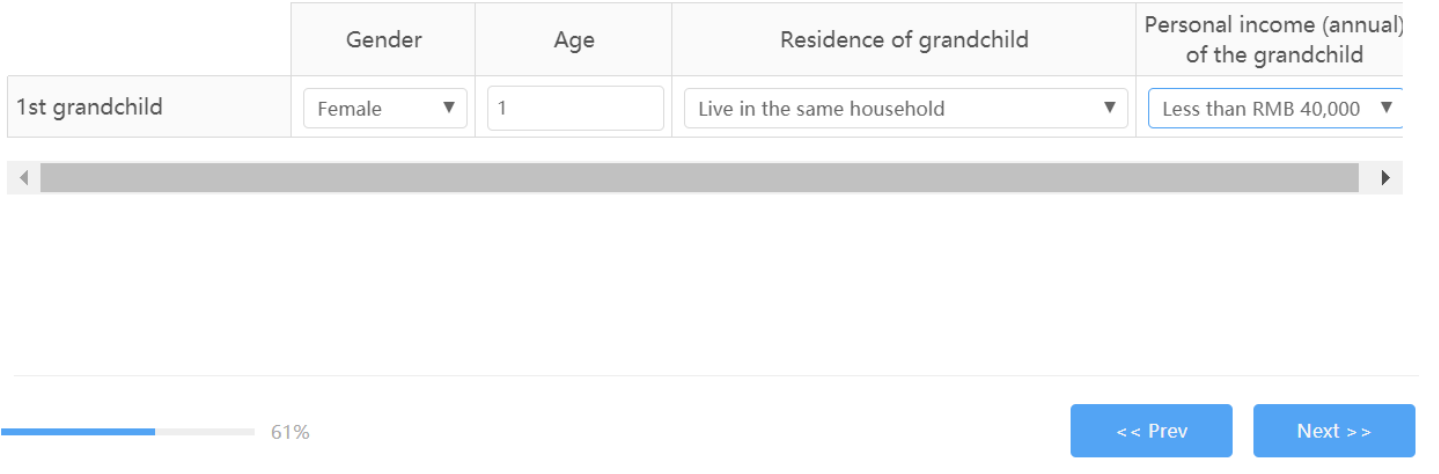

\section{Demographics and health}

Do you/your spouse have social health insurance?

Myself:

Spouse:

\section{Demographics and health}

Excluding all mortgages, what is the total value of your household debt? (including for example money borrowed from relatives, friends, or using credit cards, and bank loans other than mortgages)

RMB $0-2,000$

RMB 2,000-9,999

RMB 10,000-49,999

RMB 50,000-99,999

RMB 100,000-249,999

RMB 250,000-499,999

RMB 500,000-999,999

RMB $1,000,000$ or more 


\section{Demographics and health}

What was your household income (including bonuses and pension income) in the last year after paying tax and social security contributions?
RMB 0-39,999 per year
RMB 40,000-69,999 per year
RMB 70,000-119,999 per year
RMB 120,000 or more per year

\section{Demographics and health}

Please provide more details about your household income. What was your household income (including bonuses and pension income) in the last year after paying tax and social security contributions?

RMB $120,000-149,999$ per year
RMB $150,000-199,999$ per year
RMB $200,000-299,999$ per year
RMB 300,000 or more per year

\section{Demographics and health}

Do you smoke now?

Ever smoked, currently smoking

Ever smoked, currently not smoking

Never smoked 


\section{Demographics and health}

Compared to the population, what do you think are the chances you will ever need formal care at home?

Higher probability of needing formal care at home than the average for people of your age and gender

Lower probability of needing formal care at home than the average for people of your age and gender

\section{Demographics and health}

Compared to the population, what do you think are the chances you will ever need formal care in a residential nursing home?

Higher probability of needing formal care in a residential nursing home than the average for people of your age and gender

Lower probability of needing formal care in a residential nursing home than the average for people of your age and gender

\section{Demographics and health}

Would you say your/your spouse's health is excellent, very good, good, fair, or poor?

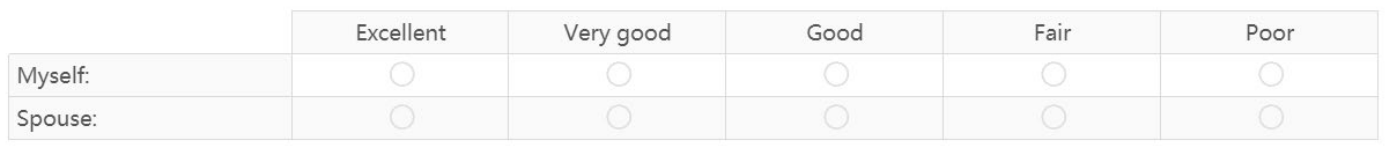

Spouse: 


\section{Demographics and health}

Compared to one year ago, how would you rate your health in general now?

Much better now

Somewhat better now

About the same

Somewhat worse now

Much worse now

\section{Demographics and health}

What is the highest level of education you have attained?

No schooling

Primary School

Junior middle school

High school (高中) or Specialised secondary schools (中專)

Two-Year College degree or Diploma (大专)

Bachelor degree from Four-Year University (大学本科)

Master or above

Have you seen this question before?

Yes

No 
1.Demographics and health

To what age do you think your spouse is going to live? Answer:

years 


\section{Financial Competence and Planning}

This set of questions covers financial literacy, numeracy, knowledge of financial products and retirement planning

\section{Financial literacy}

Suppose you had RMB 100 in a savings account and the interest rate was $2 \%$ per year. After 5 years, how much do you think you would have in the account if you left the money to grow?

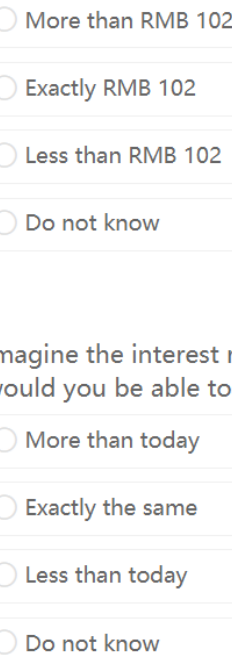

Imagine the interest rate in your savings account is $1 \%$ per year and inflation is $2 \%$ per year. After 1 year, how much would you be able to buy with the money in this account?

Please evaluate whether this statement is true or false. "Buying shares of a single company usually provides a safer return than buying units in a managed share funds".

True

False

Do not know 


\section{Financial Competence and Planning}

\section{Numeracy}

Imagine that we rolled a fair, six-sided die 1,000 times. Out of 1,000 rolls, how many times do you think the die would come up even $(2,4$, or 6$)$ ?

Please enter a number between 0 and 1,000 in the box.

Answer: times

In a lottery, the chances of winning a RMB 500 prize is $1 \%$. What is your best guess about how many people would win the prize if 1,000 people each buy a single ticket to the lottery?

Please enter a number between 0 and 1,000 in the box.

Answer:

people

In a raffle, the chance of winning a car is 1 in 1,000 . What percent of tickets in the raffle win a car?

Please enter a percentage in the box.

Answer: percentage

\section{Financial Competence and Planning}

Financial product knowledge

Before participating in this survey, had you heard of any of the following financial products?

\begin{tabular}{|l||l|l|l|}
\hline & & \\
\hline
\end{tabular}

"House for Pension" (Reverse mortgage in China) 


\section{Financial Competence and Planning}

Retirement planning

At what age do you plan to retire? (Or at what age did you retire if you are already retired)

Answer:

years old

\section{Financial Competence and Planning}

Which of the following statements best describes your thoughts about the financial aspects of retirement?

I've not thought about what savings I will need for retirement.

I've checked out my current savings position and started to think about what I will need for retirement.

I've a firm idea of what I need for retirement and I'm not on track to reach my savings goal.

I've a firm idea of what I need for retirement and I'm on track to reach my savings goal.

\section{Financial Competence and Planning}

For many households, overall spending changes dramatically upon retirement. Please indicate below what your experience has been (if you are retired), or what your expectations are (if not retired)

My household had (or expects to have) no change in spending at retirement

My household has spent (or will spend) more after retirement than before

My household has spent (or will spend) less after retirement than before 


\section{Financial Competence and Planning}

Have you given a thought about how you will pay for long-term-care expenses before you participated in this survey?

Yes

No

\section{Financial Competence and Planning}

To what extent do the following statements apply to you? Please tick one box on the scale where 0 means 'certainly not' and 10 means 'certainly yes'.

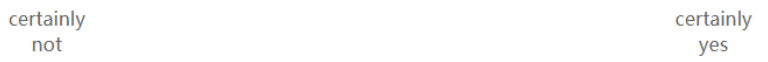

I have/expect to have enough retirement income.

I have enough savings.

I would like to leave an inheritance.

\section{Preferences and expectations}

The final set of questions covers risk preferences, patience, expectations about needing long-term care and house price expectations

\section{Risk preferences}

How do you see yourself: Are you generally a person who is fully prepared to take risks in financial matters or do you try to avoid taking risks in financial matters? Please tick one box on the scale where 0 means 'not prepared to take risks' and 10 means 'fully prepared to take risks.

$\begin{gathered}\text { Not } \\ \text { prepared } \\ \text { to take } \\ \text { risks }\end{gathered}$
0




\section{Preferences and expectations}

\section{Patience and trust}

Are you generally an impatient person or someone who always shows great patience? Please tick one box on the scale where 0 means 'very impatient' and 10 means 'very patient'.

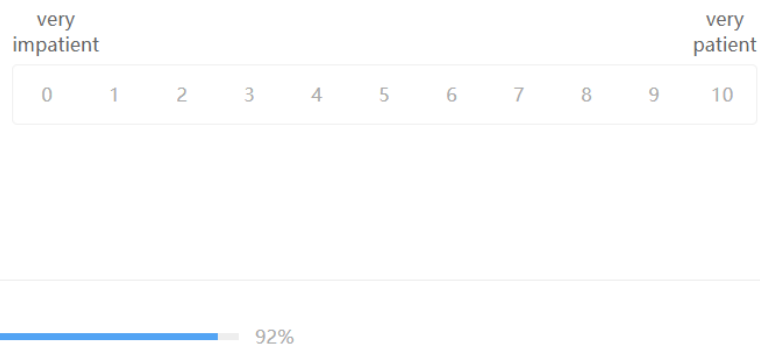

\section{Preferences and expectations}

In these questions, we ask you to describe your own personality traits. Please indicate how well each of the following describes you.

\begin{tabular}{|l|l|l|l|l|}
\hline \multicolumn{1}{|c|}{ Not at all } & A little & somewhat & good \\
\hline Organized & & & \\
\hline Responsible & & & \\
\hline Hardworking & & & \\
\hline Careless & & & \\
\hline Thorough & & & 0 \\
\hline
\end{tabular}

Thorough

\section{Preferences and expectations}

Please indicate how much you agree with the following statements. Please tick one box on the scale where 0 means 'totally disagree' and 10 means 'totally agree'.

$\begin{array}{cc}\text { totally } & \text { totally } \\ \text { disagree } & \text { agree }\end{array}$

$\begin{array}{llllllllllll}\text { Banks can generally be trusted. } & 0 & 1 & 2 & 3 & 4 & 5 & 6 & 7 & 8 & 9 & 10\end{array}$

Insurance companies can generally be trusted.

Being in debt is never a good thing. 


\section{Preferences and expectations}

\section{Long-term care expectations and preferences}

In the future when you are getting older, you may need someone to care for you and help you with your activities of daily living. In the following table, please tick all answers that apply to you.

\begin{tabular}{|c|c|c|c|c|c|}
\hline & Spouse & $\begin{array}{l}\text { Children and/or gr } \\
\text { andchildren }\end{array}$ & $\begin{array}{l}\text { Caregiver living in } \\
\text { home }\end{array}$ & $\begin{array}{l}\text { Caregiver visiting } \mathrm{h} \\
\text { ome }\end{array}$ & Nursing home \\
\hline $\begin{array}{l}\text { Who is the most likely to } \\
\text { provide care for you? }\end{array}$ & & & & & \\
\hline $\begin{array}{l}\text { Who do you prefer to pro } \\
\text { vide care for you? }\end{array}$ & & & & & \\
\hline
\end{tabular}

\section{Preferences and expectations}

\section{House price expectations}

Over the last five years, do you think the value of your home:

Increased a lot (greater than 20\%)

Increased moderately (between 5\% and 20\%)

Remained rather stable (between $5 \%$ and $-5 \%$ )

Decreased moderately (between $-5 \%$ and $-20 \%$ )

Decreased a lot (greater than -20\%)

\section{Preferences and expectations}

In the next 5 years do you think the value of your home:

Increased a lot (greater than 20\%)

Increased moderately (between $5 \%$ and $20 \%$ )

Remained rather stable (between $5 \%$ and $-5 \%$ )

Decreased moderately (between $-5 \%$ and $-20 \%$ )

Decreased a lot (greater than -20\%) 
Survey feedback

How clear do you think the questions in this survey are?

Completely clear

Mostly clear

Sometimes clear

Sometimes confusing

Mostly confusing

Completely confusing 


\section{Appendix B}

\section{B.1 The pilot reverse mortgage product in China}

Happy Life Insurance issued an income stream type RM. This contract has an embedded 'no negative equity guarantee', similar to the US home equity conversion mortgage (HECM). The 'no negative equity guarantee' property ensures that households do not have to pay anything out-of-pocket (except the housing asset) to terminate the contract. If the loan account balance is lower than the house price, the remaining proceeds will be delivered to the heirs of the household. Therefore, a household can enjoy the upside risk of the house price and the provider will bear the downside risk of the house price. It is important to note that when a household enters the contract, a loan account is set up. The loan amount will be settled when the household sells the property or passes away. The general income stream type reverse mortgage will deliver an amount of \$x per month, and this amount will be added to the loan account. In addition, an interest rate of $\mathrm{r} \%$ p.a. is charged each month on the loan account balance.

The product issued by Happy Life Insurance is further split into two streams: "with death benefit' and 'without death benefit'. For simplicity, further detail regarding the 'without death benefit' stream is presented. This product splits the retirement period of the household into two periods; the first $\mathrm{N}$ years is termed the 'deferred annuity premium paying period' and the second period the 'no premium required period'. In the first $\mathrm{N}$ years, apart from being charged \$x per month for the benefit received, the household is charged another amount, \$y, annually, and this amount is also added to the loan account at the start of each year. This amount is treated as the premium for the deferred annuity. After $\mathrm{N}$ years, i.e. upon entering the second period of the contract, the households are neither charged x per month nor y per year, but they are still eligible to the benefit of \$x per month. This is because the amount \$y per year in the first $\mathrm{N}$ years covers the rest of the benefit, which is \$x per month for the rest of the individual's life. This part can be treated as a deferred annuity. The interest rate charged each year on the loan account is fixed at the start of the contract, which is 5:5\% p.a (the current conventional mortgage rate in China is around 5\%). compounded monthly. Only individuals aged 60 to 85 are eligible to enter the contract.

The other stream of the product includes a death benefit. For this stream of the product, the deferred annuity component of the contract carries a 'Cash Value' such that when the contract is complete, the heirs of the household are eligible to receive the 'Cash Value' as a bequest. Therefore, the deferred annuity annual premium will be higher than the product without death 
benefit. In addition to the annual administrative fee and the one-off notary fee, a transaction fee and lawyer fee will be charged to the loan account. Table 5.5 illustrates the benefit received and the deferred annuity premium (in terms of RMB) paid by a male with starting age of 60 to 85 per RMB 1,000,000 housing assets.

Figure B.1: Illustrative example of the Happy Life Insurance reverse mortgage for a male aged 60

\begin{tabular}{ccc}
\hline Age & 60 & \multicolumn{1}{|}{+6} \\
Events & Start of contract & End of period $N$ \\
Amount add to loan & $12 x+y$ & 0 \\
each year & $x$ & $x$
\end{tabular}

Table B.1: Illustrative example of the Happy Life Insurance reverse mortgage for a male aged 60-85 to enter the contract comparing 'with death benefit' and 'without death benefit'.

\begin{tabular}{|c|c|c|c|c|c|}
\hline \multirow[b]{2}{*}{ Age } & \multicolumn{2}{|c|}{ Without death benefit } & \multicolumn{2}{|c|}{ With death benefit } & \multirow{2}{*}{$\begin{array}{l}\text { Deferred annuity } \\
\text { premium paying } \\
\text { period }\end{array}$} \\
\hline & $\begin{array}{l}\text { Deferred annuity } \\
\text { annual premium }\end{array}$ & Benefit per month & $\begin{array}{l}\text { Deferred annuity } \\
\text { annual premium }\end{array}$ & Benefit per month & \\
\hline 60 & 2,544 & 2,514 & 7,107 & 2,124 & 26 \\
\hline 61 & 2,850 & 2,624 & 7,830 & 2,199 & 25 \\
\hline 62 & 2,587 & 2,646 & 7,616 & 2,217 & 25 \\
\hline 63 & 2,911 & 2,766 & 8,409 & 2,296 & 24 \\
\hline 64 & 3,285 & 2,894 & 9,302 & 2,380 & 23 \\
\hline 65 & 3,719 & 3,031 & 10,312 & 2,468 & 22 \\
\hline 66 & 4,226 & 3,177 & 11,457 & 2,560 & 21 \\
\hline 67 & 4,822 & 3,334 & 12,761 & 2,656 & 20 \\
\hline 68 & 4,384 & 3,372 & 12,412 & 2,686 & 20 \\
\hline 69 & 5,034 & 3,546 & 13,891 & 2,790 & 19 \\
\hline 70 & 5,810 & 3,734 & 15,595 & 2,898 & 18 \\
\hline 71 & 6,740 & 3,938 & 17,572 & 3,013 & 17 \\
\hline 72 & 6,128 & 3,990 & 17,088 & 3,054 & 17 \\
\hline 73 & 7,173 & 4,219 & 19,348 & 3,180 & 16 \\
\hline 74 & 8,453 & 4,470 & 22,006 & 3,312 & 15 \\
\hline 75 & 10,036 & 4,744 & 25,159 & 3,453 & 14 \\
\hline 76 & 9,145 & 4,821 & 24,472 & 3,512 & 14 \\
\hline 77 & 10,992 & 5,135 & 28,174 & 3,668 & 13 \\
\hline 78 & 13,343 & 5,484 & 32,660 & 3,834 & 12 \\
\hline 79 & 12,168 & 5,584 & 31,754 & 3,911 & 12 \\
\hline 80 & 15,009 & 5,989 & 37,155 & 4,098 & 11 \\
\hline 81 & 13,651 & 6,105 & 36,064 & 4,191 & 11 \\
\hline 82 & 16,204 & 6,216 & 40,298 & 4,158 & 10 \\
\hline 83 & 14,707 & 6,344 & 39,042 & 4,266 & 10 \\
\hline 84 & 18,672 & 6,795 & 46,245 & 4,441 & 9 \\
\hline 85 & 24,667 & 7,463 & 56,710 & 4,727 & 8 \\
\hline
\end{tabular}




\section{B.2 Variable definitions}

\begin{tabular}{|c|c|}
\hline Variable & Definition \\
\hline \multicolumn{2}{|c|}{ Long-term care insurance demand } \\
\hline $\begin{array}{l}\text { Wealth allocated to } \\
\text { long-term care } \\
\text { insurance }\end{array}$ & $\begin{array}{l}\text { A numerical variable that ranges between } 0 \text { and } 1 \text {, the percentage of total wealth } \\
\text { allocated to the long-term care insurance premium }\end{array}$ \\
\hline $\begin{array}{l}\text { Preferred scenario } \\
\text { Product S/ Products S } \\
\text { and R/ Products S and } \\
\text { H }\end{array}$ & $\begin{array}{l}\text { Indicator variable that equals one if the participant prefers the scenario in which only } \\
\text { Product } \mathrm{S} \text { is available/Products } \mathrm{S} \text { and } \mathrm{R} \text { are available/Product } \mathrm{S} \text { and } \mathrm{H} \text { are available } \\
\text { and zero otherwise. }\end{array}$ \\
\hline
\end{tabular}

Economic factors

Household savings

Indicator variable that equals one if the participant reports household savings excluding all properties (including saving accounts, term deposits, government bonds, stocks, shares in investment fund) above the sample median, and zero otherwise.

Household debt Indicator variable that equals one if the participant reports household debt excluding all mortgages (including for example money borrowed from relatives, friends, or using credit cards, and bank loans other than mortgages above the sample median, and zero

otherwise.

Household income Indicator variable that equals one if the participant reports a household income (including bonuses and pension income) in the last year after paying tax and social security contribution above the sample median, and zero otherwise.

Social insurance Indicator variable that equals one if the participant has social insurance, and zero otherwise

Property value Indicator variable that equals one if the participant reports a property value (in RMB $1,000,000)$ above the sample median, and zero otherwise.

Mortgage amount Indicator variable that equals one if the participant has a mortgage amount greater than the sample median, and zero otherwise.

Demographic factors

Age

Retired

Female

Married

$1+$ child

Daughter

Child same household Indicator variable that equals one if the participant has a child living in the same household, and zero otherwise.

College above

Tier 1 city

A polychotomous variable that equals one if the participant is 45-49 years and rising by one in five-year steps.

Indicator variable that equals one if the participant is retired, and zero otherwise.

Indicator variable that equals one if the participant is female, and zero for male.

Indicator variable that equals one if the participant is married (including living in a long-term partnership), and zero otherwise.

Indicator variable that equals one if the participant has at least one child, and zero otherwise.

Indicator variable that equals one if the participant has at least one daughter, and zero otherwise.

Indicator variable that equals one if the highest level of education attained by the participant is a college degree or above, and zero otherwise.

Indicator variable that equals one if the participant lives in a Tier I city, and zero otherwise. 
Health

Subjective life expectancy

Smoker
Indicator variable that equals one if the participant's self-rated health status on a fivepoint scale $(1=$ excellent $\ldots 5=$ poor, coded reversely $)$ is above the sample median, and zero otherwise.

Indicator variable that equals one if the participant's subjective life expectancy is above the sample median, and zero otherwise.

Indicator variable that equals one if the participant is a current smoker, and zero otherwise

Personality and expectations

Financial literacy and numeracy

Awareness of financial products

Awareness of longterm care insurance

Awareness of RM

House price expectation

Trust in banks

Trust in insurer

Thought of long-term care

Intended bequest
Indicator variable that equals one if the participant's financial literacy and numeracy score based on six questions are each above the sample median, and zero otherwise.

Indicator variable that equals one if the number of the thirteen listed financial products that the participant had heard of is above the sample median, and zero otherwise.

Indicator variable that equals one if the participant had heard of long-term care insurance before participating in the survey, and zero otherwise.

Indicator variable that equals one if the participant had heard of reverse mortgages before participating in the survey, and zero otherwise.

Indicator variable that equals one if the participant expects the value of the property to increase a lot (more than 20\%) or increase moderately $(5 \%-20 \%)$, and zero otherwise.

Indicator variable that equals one if the participant's rating of the statement "Banks can generally be trusted" on an eleven-point scale $(0=$ Totally disagree... $10=$ Totally agree) is above the sample median, and zero otherwise.

Indicator variable that equals one if the participant's rating of the statement "Insurance companies can generally be trusted." on an eleven-point scale $(0=$ Totally disagree... $10=$ Totally agree) is above the sample median, and zero otherwise.

Indicator variable that equals one if the participant has thought about how to pay for long-term care expenses before participating in the survey, and zero otherwise

Indicator variable that equals one if the participant's rating of the statement "I would like to leave an inheritance." on an eleven-point scale $(1=$ Certainly not $\ldots 10=$ Certainly yes) is above the sample median, and zero otherwise.

Product and survey understanding

Subjective product understanding

Product quiz

Survey clarity

Passed IMC

Survey time
Indicator variable that equals one if the participant's self-rated product understanding in Tasks 1, 2, and 3 are all above the sample median, and zero otherwise.

Indicator variable that equals one if the participant's number of correct answers to the product quiz questions is above the sample median, and zero otherwise

Indicator variable that equals one if the participant's rating of the survey's clarity on a six-point scale $(1=$ completely clear ... $6=$ completely confusing, coded reversely) is above the sample median, and zero otherwise.

Indicator variable that equals one if the participant answered the instructional manipulation check correctly, and zero otherwise.

Indicator variable that equals one if the time taken by the participant to complete the survey was above the sample median, and zero otherwise.

\section{Treatments}

Product R first

High premium in example
Indicator variable that equals one if the participant saw Product $\mathrm{R}$ before Product $\mathrm{H}$, and zero otherwise.

Indicator variable that equals one if the participant saw the example with higher premiums 


\section{B.3 Pricing of the long-term care insurance products}

\section{B.3.1 CLHLS and CHARLS data}

We use data from the Chinese Longitudinal Healthy Longevity Survey (CLHLS) and the China Health and Retirement Longitudinal Study (CHARLS) to estimate the health transition model. CLHLS and CHARLS contain detailed information on health status, socioeconomic characteristics, family structure, and other demographic covariates of the elderly in different areas of China.

CLHLS is conducted by the Center for Healthy Aging and Family Studies at the National School of Development at Peking University. The baseline survey of CLHLS was conducted in 1998 and covered 22 provinces in China. The data were collected from face-to-face homebased interviews and physical capacity tests. The CLHLS targets the elderly aged 80 or above in the sample cities and rural areas. Follow-up surveys were conducted in 2000, 2002, 2005, 2008, 2011, 2014, and 2018, and these surveys contain replacements for deceased elderly. From 2002, CLHLS has been expanded to target a broader group of the population, including elderly aged 65 or above, and collects a large set of health, disability, demographic, family, socioeconomic, and behavioral risk factors.

CHARLS is conducted by the China Center for Economic Research at Peking University. The baseline survey of CHARLS was conducted in 2011 and 2012 and covered 28 provinces in China. The target population of these surveys is elderly aged 45 or above in the sample cities and rural areas. Follow-up surveys were conducted in 2013, 2015, and 2018.

We designed the experimental survey for this chapter in 2018-2019 and used CLHLS and CHARLS data for 2000-2015. Our sample includes individuals who are aged above 45 living in the urban area. The total sample size of the CLHLS and CHARLS is 28,354, but a lot of observations are in older ages. As the data was not collected regularly, we use the age of each individual at the beginning and the end of the period to determine the transition period. We estimate the model using one-year age groups for the age range 65-99. We group all the individuals aged 100 or above in the "100+" group and those aged below 65 will be grouped in a five-year interval, i.e., 45-49, 50-54, 55-59, and 60-64. We estimate separate models for males and females.

We use ADL limitations as the measure of health states. Six ADL items were evaluated in both CLHLS and CHARLS: bathing, dressing, eating, using the toilet, continence, and transferring in and out of bed. Individuals reported their ability to perform these activities using three 
categories: do not need help, need partial help, and need full assistance. We classify an individual as being able to perform an ADL only if they do not need help. We define an individual as disabled if he/she has difficulties performing at least 3 of the ADLs. This definition is one of the triggers of benefit payments for many existing private critical illness insurance policies in China, such as the policies issued by Ping An Insurance and China Pacific Insurance.

We calculate the central exposed to risk for both healthy and disabled health states using the exact interview date, birth date, and death date. If these dates are missing, we use the $15^{\text {th }}$ of the reported month. We assume that the transitions of health states happened in the mid-point between two survey waves.

\section{B.3.2 Generalized linear model (GLM)}

Following previous actuarial research (Renshaw and Haberman, 1995; Fong et al., 2015; Hanewald et al., 2019), we consider a Markov process as the basis for modeling long-term care status transitions and apply generalized linear models to estimate the transition probabilities. We consider a three-state Markov process as shown in Figure 5.10. The three health states are "N" (nondisabled), "F" (functionally disabled), and "D" (dead, absorbing state).

Figure B.2: Three-State Markov Process.

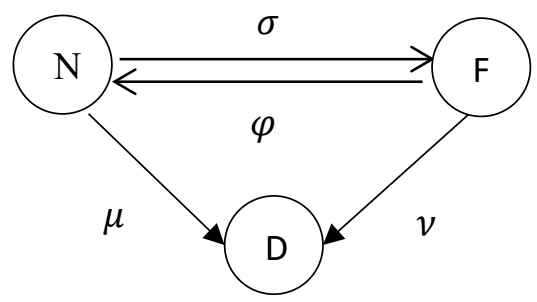

We consider four health transitions:

- $\sigma: N \rightarrow F$, the intensity for a healthy individual to become functionally disabled

- $\varphi: F \rightarrow N$, the intensity for a functionally disabled individual to recover

- $\mu: N \rightarrow D$, the mortality intensity for a healthy individual

- $\quad v: F \rightarrow D$, the mortality intensity for a functionally disabled individual

The transition probabilities are assumed to follow a time-homogenous Markov process, which is time-independent, and where the transition probabilities only depend on the current state but not the history. So, we have the following equation:

$$
P_{i, j}(x, t)=\operatorname{Pr}(S(x+t)=j \mid S(x)=i)
$$


Under the GLM approach, there are three components to be specified: the probability distribution, the linear predictor, and the link function.

Probability distribution: The transition intensities of each one-year age group are assumed to be constant in a given time interval (between two survey waves), and the number of transitions is assumed to follow a Poisson distribution. In the following, we use the mortality intensities of a healthy individual at age $x$ as an example to show the relationships of linear predictor and link function with the intensities. Let $n_{x}^{h, d}$ be the number of transitions from state $H$ to $D$ at age $x:$

$$
n_{x}^{h, d} \sim \operatorname{Poisson}\left(e_{x}^{H} \mu_{x}\right),
$$

where $e_{x}^{H}$ represents the central exposed to risk of the health state $H$ at age $x$.

Linear predictor: Following Fong et al. (2015), we model the health transitions as polynomial functions of age. Therefore, the linear predictor is given by:

$$
\eta_{x}=\beta_{0}+\sum_{i=1}^{n} \beta_{i} x^{i}
$$

where $x$ represents the age, and $\beta_{i}$ are the coefficients to be estimated.

Link function: We use the log link function $g(\cdot)$ as in Fong et al. (2015) and Hanewald et al. (2019). Following the example above, we have the following link function:

$$
g\left(\mu_{x}\right)=\ln \left(\mu_{x}\right)=\eta_{x}
$$

\section{Model estimation}

We use maximum likelihood estimation to estimate the parameters of the GLMs. Let $\Phi$ be the set of parameters. The log-likelihood function is given by (using the mortality intensities of a healthy individual as an example):

$$
l(\Omega)=\sum_{x}\left[n_{x} \ln \left(e_{x}^{H} \mu_{x}(\Phi)\right)-e_{x}^{H} \mu_{x}(\Phi)\right]
$$

We use the Bayesian information criterion (BIC) to choose the functional form in Equation (2). We select the model with the smallest BIC value as the preferred model under the proposed GLM. Table 5.7 shows the BIC of the four nested models, while Table 5.8 shows the coefficients of the selected model. 
Table B.2: BIC for different nested models.

\begin{tabular}{cccccc}
\hline & Model & $\beta_{0}$ & $\beta_{0}+\beta_{1} x$ & $\beta_{0}+\beta_{2} x^{2}$ & $\beta_{0}+\beta_{1} x+\beta_{2} x^{2}$ \\
$\sigma$ & Male & $1,036.37$ & 441.51 & $\mathbf{4 3 5 . 6 9}$ & 438.06 \\
& Female & $1,500.77$ & $\mathbf{5 6 8 . 4 6}$ & 577.09 & 569.48 \\
& Male & $3,835.29$ & 546.23 & 644.36 & $\mathbf{5 4 5 . 9 4}$ \\
$\mu$ & Female & $4,577.01$ & 531.58 & 727.17 & $\mathbf{4 6 9 . 2 9}$ \\
& Male & 314.21 & 296.92 & 301.7 & $\mathbf{2 9 6 . 4 7}$ \\
$\gamma$ & Female & 460.75 & $\mathbf{3 8 4 . 8 2}$ & 388.77 & 389.2 \\
& Male & 618.98 & $\mathbf{3 9 9 . 1 2}$ & 409.57 & 401.4 \\
$v$ & Female & 613.21 & $\mathbf{3 6 8 . 9 6}$ & 374.31 & 373.34 \\
\hline
\end{tabular}

Table B.3: Coefficients of different nested models.

\begin{tabular}{cccccc}
\hline & Model & $\beta_{0}$ & $\beta_{0}+\beta_{1} x$ & $\beta_{0}+\beta_{2} x^{2}$ & $\beta_{0}+\beta_{1} x+\beta_{2} x^{2}$ \\
& Male & $-5.219^{* * *}$ & -- & $9.414^{* * *}$ & $-5.219^{* * *}$ \\
& Female & $-6.231^{* * *}$ & $6.944^{* * *}$ & -- & $-6.231^{* * *}$ \\
& Male & $-6.555^{* * *}$ & $1.182^{* * *}$ & $3.440^{*}$ & $-6.555^{* * *}$ \\
& Female & $-9.165^{* * *}$ & $22.599^{* * *}$ & $15.165^{* * *}$ & $-9.165^{* * *}$ \\
\multirow{4}{*}{$\gamma$} & Male & $-1.191^{* * *}$ & $-6.826^{* *}$ & $7.124^{*}$ & $-1.191^{* * *}$ \\
& Female & $-1.135^{* * *}$ & $3.362^{* * *}$ & -- & $-1.135^{* * *}$ \\
\multirow{2}{*}{$v$} & Male & $-3.824^{* * *}$ & $5.557^{* * *}$ & -- & $-3.824^{* * *}$ \\
& Female & $-3.843^{* * *}$ & $5.220^{* * *}$ & -- & $-3.843^{* * *}$ \\
\hline
\end{tabular}

After estimating the GLMs, we calculate the health state transition matrix. The following matrix is an example for a male aged $x$ :

$$
T_{\text {male }}(x, x+1)=\left[\begin{array}{ccc}
p_{N, N}^{\text {male }}(x, x+1) & p_{N, F}^{\text {male }}(x, x+1) & p_{N, D}^{\text {male }}(x, x+1) \\
p_{F, N}^{\text {male }}(x, x+1) & p_{F, F}^{\text {male }}(x, x+1) & p_{F, D}^{\text {male }}(x, x+1) \\
0 & 0 & 1
\end{array}\right],
$$

where $p_{y, z}^{\text {male }}(x, x+1)$ is the transition probability that the individual transitions from health state $y$ to health state $z$ between age $x$ and age $x+1$.

\section{Calculation of the long-term care insurance premium}

In the experimental task, all individuals are assumed to be healthy and age 60 for males or 55 for females. To calculate the transition probabilities to age $60+a$ of a healthy male aged 60 , we use the following matrix multiplication:

$$
\begin{array}{r}
{\left[p_{h, h}^{\text {male }}(60,60+a) \quad p_{h, f}^{\text {male }}(60,60+a) \quad p_{h, d}^{\text {male }}(60,60+a)\right]} \\
=\left[\begin{array}{lll}
1 & 0 & 0
\end{array}\right] \times \prod_{i=1}^{a} T_{\text {male }}(60+i-1,60+i) .
\end{array}
$$

Each entry of the resulting array is the probability of the transition from healthy to the corresponding health state at age $60+a$ of a healthy male aged 60. Assuming a limiting age 
of 100 , we can use the above formula to obtain the transition probabilities to age 61 up to 100 by varying $a$ from 1 to 40 .

The long-term care insurance premium is given by the total expected present value of the benefit, which is the income when the individual becomes disabled. The formula for males is

$$
\mathrm{E}\left[\mathrm{LTCI}^{\text {male }}\right]=\sum_{t=1}^{40} \mathrm{E}\left[\text { benefit }{ }_{t}^{\text {male }}\right] \times D F_{t}
$$

where $D F_{t}$ is the discount factor for the cash flow in $t$ years' time. The long-term care insurance premium for females is calculated using the same methodology.

The long-term care insurance premium for a couple is given by:

$$
\mathrm{E}\left[\mathrm{LTCI}^{\text {total }}\right]=\mathrm{E}\left[\mathrm{LTCI}^{\text {male }}\right]+\mathrm{E}\left[\mathrm{LTCI}^{\text {female }}\right] .
$$

We assume a profit loading of $20 \%$ so that the final long-term care insurance premium is 1.2 times the expected present value.

\section{B.3.3 Reverse mortgage}

The initial loan of the reverse mortgage component is the price of long-term care insurance. We allow for a maximum loan-to-value ratio at the start of the contract of $40 \%$. In the reverse mortgage pilot program in China, the interest rate charged is $5.5 \%$ p.a. plus annual management and policy fees. To simplify the fee structure, we assume no additional fees but instead assume a higher interest rate to capture the fees. We estimate that for an initial loan of RMB 1 million, for a male aged 60 entered into the pilot reverse mortgage agreement, with a life expectancy of 30 years, the management fee is around $0.3 \%$ p.a. Therefore, we use an interest rate of $5.8 \%$ p.a. for the reverse mortgage loan.

\section{B.3.4 Home reversion plan}

Assuming a similar product design as in Alai et al. (2014), the home reversion contract involves selling a proportion $\kappa$ of home equity to the contract provider to finance the long-term care insurance premium. A lease-for-life is embedded in the contract, which reflects the rent on the proportion of the home sold. Therefore, the sale proceeds consist of two components, the leasefor-life agreement and the amount that can be used to finance the long-term care insurance premium, so the following relationship holds:

$$
\kappa H_{0}=L L+\text { amount can be used for LTC insurance, }
$$

where $H_{0}$ is the current house price, and $L L$ is the value of the lease-for-life agreement. 
Let the rental yield be the constant $R Y$. In each period, the value of the lease-for-life agreement would increase if they remain in the property. Assume the house price growth rate is $g$ each year. Then, the EPV of the lease-for-life agreement is:

$$
\left.L L=\kappa H_{0} \times \sum_{t=1}^{\omega-55} D_{t} \times R Y \times(1+g)^{t} \times \operatorname{Pr} \text { (stay in the home } \mathrm{t}_{\mathrm{t}}\right)
$$

where $\omega$ is the limiting age, which is $100 . \operatorname{Pr}$ (stay in the home $_{t}$ ) is the probability that the couple will stay in the property for $t$ years, which we calculate as:

$$
\begin{gathered}
\operatorname{Pr}(\text { stay in the home } \mathrm{t})=1-\operatorname{Pr}\left(\text { moving out }_{\mathrm{t}}\right) \\
=1-p_{h, f}^{\text {male }}(60,60+t) \times\left(p_{h, f}^{\text {female }}(55,55+t)+p_{h, d}^{\text {female }}(55,55+t)\right) \\
-p_{h, d}^{\text {male }}(60,60+t) \times\left(p_{h, f}^{\text {female }}(55,55+t)+p_{h, d}^{\text {female }}(55,55+t)\right) .
\end{gathered}
$$

First, we compute the probability of the couple moving out of the property. The couple will need to move out of the property only when both are functionally disabled, one of them is dead and the other one is functionally disabled, or both are dead. As the sum of the probabilities of staying in the property and moving out of the property equals one, by rearranging the equation, the probability of staying in the property can be obtained. Therefore, to pay RMB 1 of longterm care insurance premium, the proportion of the property to sell is:

$$
\kappa=\frac{1}{H_{0} \times\left(1-\sum_{t=1}^{\omega} D_{t} \times R Y \times(1+g)^{t} \times \operatorname{Pr}(\text { stay in the home } \mathrm{t})\right)} .
$$




\section{B.3.5 Data sources}

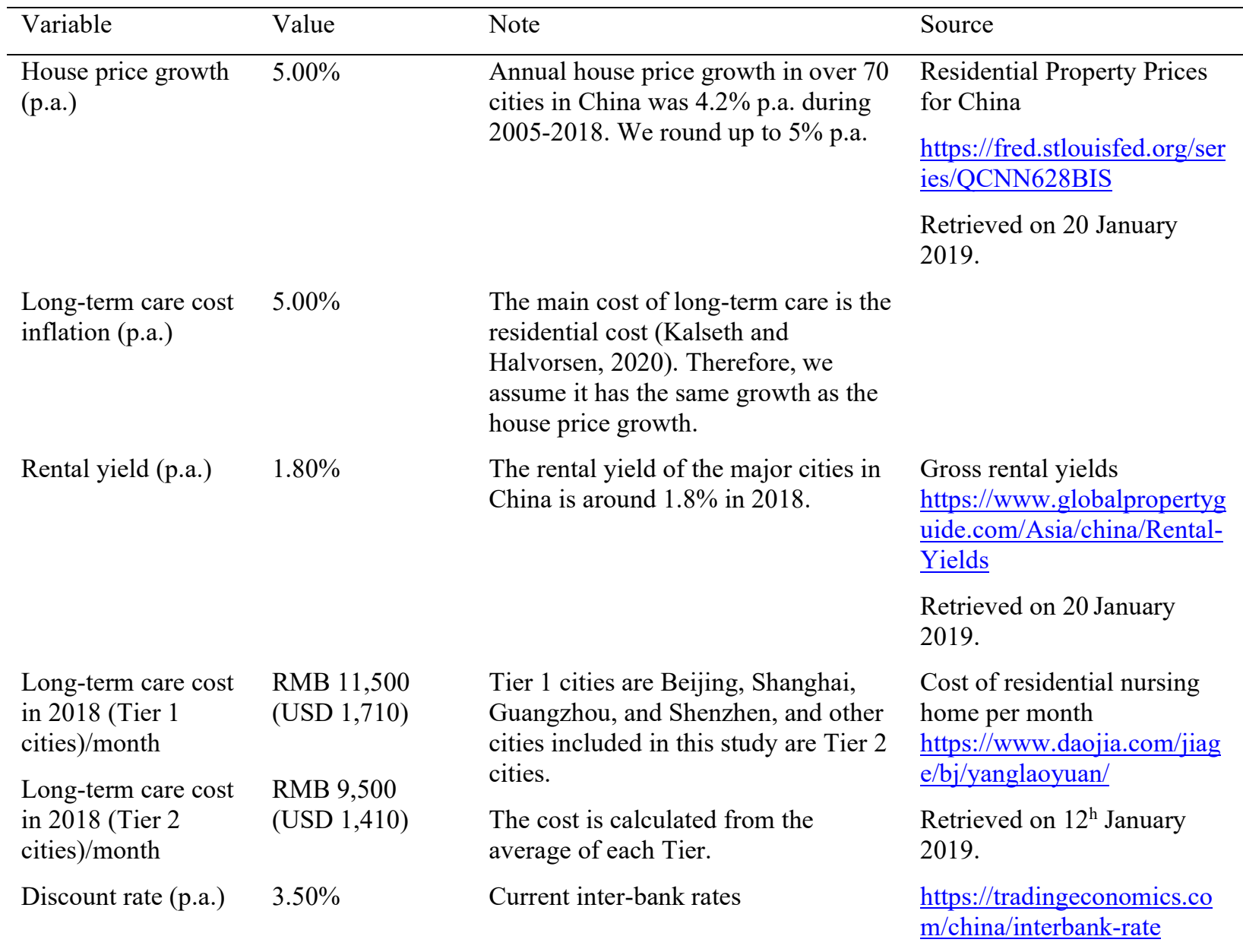

\section{References}

Fong, J. H., Shao, A. W., \& Sherris, M. (2015). Multistate actuarial models of functional disability. North American Actuarial Journal, 19(1): 41-59.

Hanewald, K., Li, H., \& Shao, A. W. (2019). Modelling multi-state health transitions in China: A generalised linear model with time trends. Annals of Actuarial Science, 13(1): 145-165.

Kalseth, J., \& Halvorsen, T. (2020). Health and care service utilisation and cost over the lifespan: a descriptive analysis of population data. BMC Health Services Research, 20: 1-14.

Renshaw, A. E., \& Haberman, S. (1995). On the graduations associated with a multiple state model for permanent health insurance. Insurance: Mathematics and Economics, 17(1): 117. 